\title{
INTERNATIONAL CAPITAL MOBILITY \\ IN HISTORY: THE SAVING-INVESTMENT \\ RELATIONSHIP
}

Alan M. Taylor

Working Paper 5743

\author{
NATIONAL BUREAU OF ECONOMIC RESEARCH \\ 1050 Massachusetts Avenue \\ Cambridge, MA 02138 \\ September 1996
}

This work is related to a larger project with Maurice Obstfeld (Obstfeld and Taylor 1996) on the historical evolution of international capital mobility. I am indebted to Pierre Sicsic, Matthew Jones, Maurice Obstfeld, and Barry Eichengreen for help with data enquiries. For their helpful comments I wish to thank Joel Mokyr, Timothy Hatton, Nicholas Crafts, and participants in seminars at Queen's University, the University of Toronto, the NBER program meeting on the Development of the American Economy (March 1996), and the Econometric Society Seventh World Congress (Tokyo, August 1995). Comments are very welcome. All errors are mine. This paper is part of NBER's research programs in the Development of the American Economy, and International Finance and Macroeconomics. Any opinions expressed are those of the author and not those of the National Bureau of Economic Research.

(C) 1996 by Alan M. Taylor. All rights reserved. Short sections of text, not to exceed two paragraphs, may be quoted without explicit permission provided that full credit, including $(\subset$ notice, is given to the source. 


\title{
INTERNATIONAL CAPITAL MOBILITY \\ IN HISTORY: THE SAVING-INVESTMENT \\ RELATIONSHIP
}

\begin{abstract}
Economic historians have been concerned with the evolution of international capital markets over the long run, but empirical testing of market integration has been limited. This paper augments the literature by investigating long- and short-run criteria for capital mobility using time-series and cross-section analysis of saving-investment correlation for twelve countries since 1850 . The results present a nuanced picture of capital market evolution. The sample shows considerable cross-country heterogeneity. Broadly speaking, the inter-war period, and especially the Great Depression, emerge as an era of diminishing capital mobility, and only recently can we observe a tentative return to the degree of capital mobility witnessed during the late nineteenth century.
\end{abstract}
Alan M. Taylor
Department of Economics
Northwestern University
2003 Sheridan Road
Evanston, IL 60208-2600
and NBER
amt@nwu.edu 


\section{Introduction}

Although economic historians have long been concerned with the evolution of international capital markets over the long run, empirical testing of market integration criteria has been limited. The conventional wisdom suggests that late-nineteenth century capital markets were relatively well integrated under the classic gold standard centered on London; that the inter-war period was one of disintegration and imperfect capital mobility, especially after 1929; and that the postwar period has been characterized by gradually increasing capital market integration. This paper seeks to confront and test such hypotheses using quantity criteria on the saving-investment relationship applied to the longest and broadest panel data sets assembled for this purpose.

The evolution of international capital mobility is, in principle, closely tied to the trends and cycles in foreign lending. Yet the presence of flows, is neither a necessary nor sufficient condition for market integration: a small autarkic country with capital scarcity no different from the "world" market will exhibit no incipient flows upon opening itself to capital flows. Conversely, countries with substantial barriers to capital mobility may nonetheless experience capital flows of some sort provided international rate-of-return differentials are sufficiently large. Here, then, is the handicap of using quantity rather than price criteria as yardsticks of market integration.

Is there any logic to using quantity criteria at all? First, price criteria are not without problems. They are intense in data requirements, and studies need to focus on identical assets in different markets, such as the onshoreoffshore price differential on a given asset - and, in practice, such data series are few (Obstfeld 1994). Second, quantity criteria do bear on certain predictions of economic theory. For example, presumptions of consumptionsmoothing preferences can be tested by looking at quantity data on consumption and income across time, to see whether income shocks are adequately smoothed away: that is, whether international risk-sharing functions satisfactorily. Of course, income minus consumption is equal to saving, so this is not unrelated to the saving-investment criterion, which instead asks whether shocks to investment are constrained by local saving supply, or whether they are met by the global pool of capital. Thus, despite shortcomings, a substantial literature has evolved using quantity criteria for evaluating capital mobility. A seminal contribution was that of Feldstein and Horioka (FH) (1980) which used data for the 1960s and 1970s on savings and investment rates to assess whether incremental savings were retained in the home coun- 
try or else entered the global capital market seeking out the highest return. This paper develops and extends the historical application of the $\mathrm{FH}$ approach (and its subsequent refinements), and seeks to extend the empirical framework and historical scope of the analysis in several ways.

It is natural to ask what exogenous or endogenous changes in policy, institutions or market structure might have implied for capital mobility. By applying the criteria in different time periods, corresponding to major changes in policy regimes, I can begin to attack the question. I also reassess the methodology applied to evaluate capital mobility criteria, subjecting the Feldstein-Horioka test in historical application to further scrutiny. I am able to apply not just the traditional FH estimator, but also panel tests of pooling, and comparisons with time-series estimates derived from a recently proposed error-correction model of the saving-investment relationship. My tests have enhanced power compared to other historical studies, since I increase the sample size: I use annual data for the full period 1850 to the present, and I increase the cross-section size from the usual nine or ten up to twelve, by including an important capital receiving region of the late nineteenth century, Argentina, an important capital exporter of the late nineteenth century, France, and a major recent capital exporter, Japan. ${ }^{1}$

I contrast the results of standard tests of long-run capital mobility (savinginvestment correlations in cross section) and alternative tests of short-run capital mobility (saving-investment correlations in time series), and conclude that the two approaches offer helpful and complementary insights into the evolution of the "world" capital market. In the end, a consistent story of international capital market evolution can be told. The results present a more nuanced picture of capital market evolution: in the Feldstein-Horioka sense, the long-run capital-mobility parameters exhibit considerable fluctuation across time; and the short-run parameters evolve very differently in the several sample countries studied.

\footnotetext{
${ }^{1}$ As noted elsewhere, on a relative scale, Argentina was the New World region most dependent on capital imports under the classic gold standard, with about half the capital stock foreign-owned circa 1914, a figure far in excess of any other country before or since, and a situation which made sustained growth extremely vulnerable to international capital market disruption (Díaz-Alejandro 1970; Taylor 1992; Taylor 1994b).
} 


\section{Capital Flows in the Nineteenth and Twen- tieth Centuries}

As noted, analysis of the saving-investment relationship is closely tied to the study of the pattern of capital flows, by dint of the saving-investment identity. Some definitions and notation will now prove useful. To simplify, we may define gross national product $Q$ as the sum of goods produced, which, with imports $M$, may be allocated to private consumption $C$, public consumption $G$, investment $I$, or export $X$, so that $Q+M=C+I+G+X$. Rearranging, GNP is given by

$$
\mathrm{GNP} \equiv Q=C+I+G+N X,
$$

where $N X=X-M$ is net exports. If the country's net credit (debt) position vis-à-vis the rest of the world is $B(-B)$, and these claims (debts) earn (pay) interest at a world interest rate $r$, then gross domestic product is GNP plus (minus) this net factor income from (to) the rest of the world,

$$
\mathrm{GDP} \equiv Y=Q+r B=C+I+G+N X+r B
$$

It is then straightforward to show that the net balance on the current account $C A$ satisfies

$$
C A \equiv N X+r B=(Y-C-G)-I=S-I,
$$

where $S \equiv Y-C-G$ is gross national saving. ${ }^{2}$ Finally, the dynamic structure of the current account and the credit position is given by the equality of the current account $(C A)$ and the capital account $(K A)$, so that

$$
B_{t+1}-B_{t} \equiv K A_{t}=C A_{t}
$$

Thus, for example, an export creates a current account credit, a related capital account inflow as the trading partner finances the purchase, and a corresponding change in the net credit position of the country.

This study will focus on the patterns of saving $(S)$, investment $(I)$, and the current account $(C A)$ as defined above. The basic identity $C A=S-I$ is central to my analysis. In terms of historical data collection, it proves essential to utilize the identity to measure saving residually, as $S=I+C A$,

\footnotetext{
${ }^{2} S$ is thus equal to the sum of private saving $S_{\text {priv }} \equiv Y-T-C$ and public saving $S_{\text {pub }} \equiv T-G$, where $T$ is tax revenue.
} 
because no national accounts before the 1940s present independent saving estimates, only investment and current-account data. In terms of econometrics, however, this procedure may also introduce biases (via errors in variables) in the traditional cross-section correlation analysis which must be considered. In terms of theory, the long-run constraints on current-account balance (a "no-Ponzi-game" condition) have suggested to numerous scholars the inevitability of an equilibrium level of $C A$, inviting the innovative use of a dynamic time-series model of saving and investment in the historical setting with the present sample.

Since the current account is so central to the analysis it is worth spending a moment to look at the long-run behavior of capital flows in my sample. A sense of the changing patterns of international financial flows can be gleaned by examining their trends and cycles. This could be taken to mean the absolute quantity of the capital flows themselves, but it is more informative to normalize by country size. Measurement traditionally focuses on the size of the current account balance $C A$, equal to net foreign investment, as a fraction of national income $Y$. Thus $(C A / Y)_{i t}$ becomes the variable of interest, for country $i$ in period $t$.

Table 1 and Figure 1 present the basic trends in foreign capital flows. Two measures of the extent of capital flows are used, both of which measure the cross-sectional dispersion of $(C A / Y)_{i t}$ for fixed $t$. First, the variance $\sigma_{C A / Y, t}^{2}$; second, the mean absolute value $\mu_{|C A / Y|, t}$. Quinquennially averaged data are used throughout, and the years covered for each country are shown in Table 2.

Both measures show similar patterns across time. Consider $\mu_{|C A / Y|}$. The average size of capital flows in this sample was often as high as $4 \%-5 \%$ of national income before World War I. At its first peak it reached $4.6 \%$ in the overseas investment boom of the late 1880s. This dropped back to around $3 \%$ in the depression of the 1890s. The figure approached $4 \%$ again in 1910-14, and wartime lending pushed the figure over $5 \%$ in $1915-19$. Flows diminished in size in the 1920s, however, and international capital flows were less than $1.5 \%$ of national income in the late 1930s. Again, wartime loans raised the figure in the 1940s, but in the 1950s and 1960s, the size of international capital flows in this sample reached an all time low, around $1 \%$ of national income. Only in the late 1970s and 1980s have flows increased, though not to levels above those of a century ago.

Of course, mere flow data, as a quantity criterion, serves only as weak evidence of changing market integration. The presence of flows may be guar- 
anteed despite considerable barriers to mobility, if return differentials are sufficiently large; conversely, the absence of flows may just reflect similarities in rates of return, even in the context of two perfectly integrated markets. However, these basic descriptive tables and figures do illustrate the record of capital flows, and offer prima facie evidence that the globalization of the capital market has been subject to major dislocations, most notably the inter-war period, with a dramatic contraction of flows seen in the Depression of the 1930s. Moreover, this low level in the volume of flows persisted long into the postwar era. We now turn to more formal tests to see whether this description, and the conventional history of world markets that points to the Depression as an era of disintegration, has broader support.

\section{The Saving-Investment Relationship in His- tory}

The starting point for the quantity-based criteria used to assess capital mobility in this paper is the seminal paper by Feldstein and Horioka (1980), which proposed saving-investment correlations as a measure of international capital mobility. Feldstein and Horioka reasoned that, in a world of perfectly mobile capital, domestic savings would seek out the highest returns in the world capital market independent of local investment demand, and by the same token the world capital market would cater to domestic investment needs independent of domestic savings supply.

Thus, Feldstein and Horioka expected to find low correlations of domestic saving and investment rates among developed countries given the conventional wisdom that international capital markets were well integrated by the 1960s and 1970s. In a surprising and provocative result, they discovered a high and significant investment-saving correlation in regressions of the form $(I / Y)_{i}=a+b(S / Y)_{i}+u_{i}$, with $b$ typically close to unity (the samples being a cross section of OECD countries with 5-year period averaging). It appeared that changes in domestic saving passed through almost fully into domestic investment, suggesting imperfect international capital mobility.

Feldstein and Horioka coined the term "savings-retention coefficient" to describe the regression coefficient $b$. Their finding of a large and significant coefficient has been replicated many times for various cross-section and timeseries samples using post-World War Two and historical data, so much so as 
to be now considered a robust result - a stylized fact, as it were (Dornbusch 1991; Feldstein and Bacchetta 1991; Frankel 1991; Obstfeld 1991; Tesar 1991; Sinn 1992).

Can such results be replicated for longer historical periods of a century or more? Are the results sensitive to the period or countries studied? And how can one interpret the result anyway? In this section, I begin with a discussion of the antecedent empirical literature, and then move on to the many methodological controversies surrounding this test. I then briefly discuss my data sources. In a new section I apply the traditional FH test, and subject the specification to various empirical checks. In another section I then explore an alternative time-series approach.

\subsection{Antecedent Historical Literature}

Some applications of the Feldstein-Horioka approach in economic history, the natural antecedents of this paper, therefore warrant mention. Bayoumi (1989) applied the Feldstein-Horioka approach to the classic gold-standard period before 1914 for a sample of eight countries. His finding that the fit was poorer, and the correlation lower, than for contemporary data, suggested that capital markets might well have been better integrated in the late-nineteenth century than today. Similar findings were also shown by Zevin (1992), using data for eight countries, in a study which merged price and quantity criteria to evaluate financial openness in the nineteenth and twentieth centuries. Zevin's $b$ was no higher than 0.51 for decades from the 1870 s to the 1920 s, certainly no higher than the measurements of the same coefficient for the 1960 s and 1970 s. $^{3}$

Of course, such samples only included eight countries, with imperfect data in many cases, a reflection of the scant historical statistics on national accounts and balance of payments for more than a handful of countries. Bayoumi's data excluded the United States for what seemed like arbitrary reasons, drawing criticism from, and prompting a reevaluation by, Eichengreen (1990). Eichengreen concluded that Bayoumi's conclusions were not so robust: the long-run correlations were typically different from zero at conventional significance levels, except for the 1902-1913 period. However, the

\footnotetext{
${ }^{3}$ Bayoumi's sample included Australia, Canada, Denmark, Germany, Italy, Norway, Sweden, U.K and used data from Mitchell. Zevin's sample included Australia, Canada, France, Germany, Italy, Norway, Sweden, U.K. and used data from Green and Urquhart (Green and Urquhart 1976; Mitchell 1983; Bayoumi 1989; Mitchell 1992; Zevin 1992).
} 
size of the coefficient did seem markedly smaller during the pre-1914 period (in the range 0.5-0.7), smaller than the near-unity coefficients of the $1920 \mathrm{~s}$ and $1930 \mathrm{~s}$, the $1960 \mathrm{~s}$ and $1970 \mathrm{~s} .{ }^{4}$

However, the conventional view that the inter-war period marked a significant curtailment in capital mobility was not overturned. Eichengreen suggested that it was not the gold standard per se that facilitated high capital mobility, arguing that the restored gold standard was not qualitatively different from its classic predecessor. Rather, government policy was possibly responsible: the restored gold standard was overseen by governments with radically changed objectives: discouraging overseas lending and intervening in the capital market to an extent not seen before 1914. It remains to be seen how this conclusion holds for a broader sample of countries and a longer span of data.

\subsection{Methodological Controversies}

Still, we might ask, what does the FH coefficient mean and how do we measure it accurately? As noted in the survey by Obstfeld (1994), the FeldsteinHorioka criterion, despite the attention it has commanded and its widespread use, is handicapped by two distinct sets of problems: First, do the regressions of investment on saving measure true and unbiased "savings retention"? Second, even if estimated accurately, what does the coefficient say about international capital mobility? These problems may be thought of as issues of implementation and interpretation.

On implementation, several issues arise. First, the basic choice of econometric specification for estimating $b$ : should one adopt annual time-series estimation for one country, or cross-section estimation for several countries during a set period (or should one even employ the occasionally attempted panel estimation)? This particular implementation question is also an interpretation question: given differences in sampling frequency, the time-series estimates of $b$ are thought to have a "natural" interpretation as measures of short-run capital mobility, whilst the cross-section estimates of $b$, if for a sufficiently long period (usually five to ten years in the literature), are given

\footnotetext{
${ }^{4}$ Eichengreen added the United States, increasing sample size to nine, addressed some data inconsistencies, and drew out the comparison for his set of nine countries for a century, 1880 through 1981, allowing a consistent comparison for the same group of countries over a very long period. He also applied variety of period averaging approaches.
} 
a "natural" interpretation as measures of long-run capital mobility. ${ }^{5}$ Second, what of the possibility of omitted variable bias? For the cross-section specifications, several plausible theoretical models suggest that growth, demographic structure, relative prices, taxes, government behavior, productivity shocks, and other variables might simultaneously affect both saving and investment and produce a spurious correlation in the simple FeldsteinHorioka bivariate regression (Obstfeld 1986; Summers 1988; Bayoumi 1990; Tesar 1991; Obstfeld 1994; Taylor 1994a). In the time-series specifications, variables like real interest rates might be important, given the failure of the stringent interest parity and other assumptions which theory suggests as prerequisites for the Feldstein-Horioka criterion to be satisfied (Frankel 1992). Third, what about the fundamental macroeconomic intertemporal identities, which assert that, in the long run, permanent investment must equal permanent saving plus some constant (initial wealth)? In this context, period averaging, if the periods are long enough, may lead to a misspecification in the cross-section approach by creating the estimation of an identity (or an approximation thereof), and one with $b$ ipso facto equal to one (Sinn 1992; Obstfeld 1994). Sinn (1992) advocates using a pure (one-period) crosssection estimator, which yields smaller estimates of $b$. This may not cure the problem altogether if countries are close to equilibrium, and does nothing to address cross-section heterogeneity (including omitted variable biases). Several authors raise these issues as crippling problems with the cross-section methodology, preferring instead to estimate the time-series specification only; some work in this vein has used a cointegration approach that incorporates a long-run equilibrium relationship between saving and investment and admits short-run disequilibrium dynamics (Miller 1988; Vikøren 1991; Jansen and Schulze 1996). The general criticism is essentially an argument against the "pooling" of time-series data, inherent in the "between" estimator used by Feldstein-Horioka, an approach which assumes away cross-country heterogeneity in the coefficients; time-series analysis provides a test for these

\footnotetext{
${ }^{5}$ Obstfeld (1994) discusses these interpretations in the light of a thought experiment: a sample of countries with pairwise uncorrelated time-series shocks to saving and investment but with mean saving and investment rates equal for each country would generate, for sufficiently large $T$ (sample periods) and $N$ (sample individuals), a near zero $b$ in time series and a near unit $b$ in cross section. Such a scenario indeed equates to one of longterm capital mobility but short-term independence of saving and investment. Conversely, one could easily envisage a hypothetical sample with zero cross-sectional correlation, but highly correlated time-series shocks to saving and investment.
} 
restrictions, as shown by Fujiki and Kitamura (1995).

In this paper, an agnostic attitude is adopted concerning the choice between time-series and cross-section methods: both will be estimated for a sample of ten countries with annual data from 1850 to 1988 . Why? The two methodologies have different interpretations, both potentially interesting. The implications of these approaches might usefully be examined for the first time in a historical context where we have the opportunity to use a complete stretch of data spanning almost a century and a half for a consistent sample. Further, the results from one of the estimation strategies might usefully inform interpretations of the results from the other estimation strategy, and vice versa: trivially, long-run capital mobility is built from a series of short-run capital movements, after all.

On interpretation, the Feldstein-Horioka approach, it is argued, provides no intrinsic absolute yardstick for measuring capital mobility. In short, even when we do estimate $b$, and even when we think we have estimated correctly, we still have no prior basis for judging how big is big, or how small is small. Hence, the imperative of employing comparative analysis: $b$ may have some meaning when compared for cross-sections at different points in time, or for time-series studies of different countries. Thus, Obstfeld's findings that $b$ appears very high (around 0.7) for the gold standard, period before 1914, a time of supposedly undisputed capital mobility, should perhaps moderate our initial puzzlement on being exposed to Feldstein-Horioka coefficient in the range 0.8-1.0 in the modern EC and OECD samples (Obstfeld 1986; 1994). This pragmatic, purely relative attitude to the interpretation of $b$ is fully embraced in the present study, where our data is ideally suited to such an approach: we have about 140 sample periods for 12 individual countries, which we may slice in a variety of cross-sections (every 10 or every 5 years) or consider as full-length time series on a country-by-country basis. The resulting samples will yield a multiplicity of cross-section and time-series estimates which can be compared across time and space to assess variations in international capital mobility from one country to the next, and from one period to the next. Hence, we have a methodological plan for this paper.

\subsection{Data}

What data might usefully be employed to apply the various saving-investment criteria for capital mobility in a historical context? The appendix documents the sources used in this paper, which yielded a set of annual time-series ob- 
servations for a group of twelve countries over the period 1850-1992. Some countries have incomplete or discontinuous data coverage, however: some do not enter the sample until several decades after 1850, and some drop out temporarily in the inter-war and wartime periods. However, reasonably comprehensive coverage was possible for the sample of countries which comprises Argentina, Australia, Canada, Denmark, France, Germany, Italy, Japan, Norway, Sweden, the United Kingdom and the United States.

The principal published sources are the statistical volumes of Brian Mitchell (International Historical Statistics, 1983, 1992) and the World Bank (WorldData on CD-ROM, 1994) and various national sources. For the provision of compiled data for the pre-1914 period adjusted for international gold flows and changes in stocks I am grateful to Matthew Jones and Maurice Obstfeld (Jones and Obstfeld 1994). All such series build on the individual labors of national statistical offices and individual scholars dedicated to the compilation and revision of national macroeconomic statistics. Like so many, I am indebted to this devoted group of researchers. A full documentation of these sources is provided in a data appendix at the end of this paper, and the complete set of data is available from the author upon request.

\section{4 "Long-Run" Capital Mobility Since 1850: Cross-Section Correlations and The Tradi- tional FH Test}

\subsection{Evidence from the FH Test}

The standard technique employed for estimating long-run capital mobility is the generic FH regression of average investment rates on a constant and average saving rates. The regression is performed on a cross section of countries indexed by $i$, where we use a "short" averaging period $T$ (say, five or ten years):

$$
(I / Y)_{i}=a^{\mathrm{FH}}+b^{\mathrm{FH}}(S / Y)_{i}+u_{i},
$$

where ${\overline{(I / Y)_{i}}}_{i}=\frac{1}{T} \sum_{1}^{T}(I / Y)_{i t},{\overline{(S / Y)_{i}}}_{i}=\frac{1}{T} \sum_{1}^{T}(S / Y)_{i t}$. The cross-section coefficient $b^{\mathrm{FH}}$ has the conventional interpretation of a long-run savingsretention coefficient for the sample of countries. In a sense, $b^{\mathrm{FH}}$ is measuring the extent to which the sample of countries deviates, on average over the sample period, from the closed-economy property whereby saving rates 
equal investment rates by identity. Since period averaging is employed the procedure attempts to abstract from business cycle fluctuations that simultaneously affect both saving and investment. The averaging also implies that this procedure has nothing to say about year-to-year (short-run) capital mobility: the ability of countries to temporarily run current-account surpluses or deficits in response to shocks at high frequencies (meaning approximately annual frequencies, or higher).

The results are shown in Table 3 and Figure 2. The table displays the econometric results and the figure displays the coefficient $b^{\mathrm{FH}}$ for both 5-year and ten-year averaging patterns. The table includes the estimated coefficient $b^{\mathrm{FH}}$ and various statistics for each cross-section regression: the $R^{2}$, plus the $t$-statistic and standard error of $b^{\mathrm{FH}}$. After 1870 the sample always includes between 9 and 12 countries - not a huge sample, but comparable in size to Feldstein and Baccheta's (Feldstein and Bacchetta 1991) sample of nine EC countries.

What do the results show? As noted earlier, before FH-type coefficients can be interpreted we require a benchmark for what constitutes a "high" or a "low" $b^{\mathrm{FH}}$. Put another way, $b^{\mathrm{FH}}$ comes equipped with no intrinsic absolute yardstick: we need to find a period we consider one of undisputed capital mobility and then compare other $b^{\mathrm{FH}}$ observations to this benchmark. Alternatively, we might search for movements in $b^{\mathrm{FH}}$ as indicators of whether saving-investment interdependence was relatively high or low for a given period. In this regard, our results present an ideal picture of the relative movements in $b^{\mathrm{FH}}$ over a century or more. Comparisons between sub-periods should allow us to infer whether long-run capital mobility has been unusually high or low during certain epochs.

\subsection{Interpretation of the FH Test}

For the present, what does the evolution of the bivariate $b^{\mathrm{FH}}$ for our sample say about long-run international capital mobility over the last century or more? Table 3 indicates that the estimated coefficient is significant in most periods, and usually positive. It occasionally exceeds unity. Still, to reiterate, absent a meaningful absolute scale for interpreting $b^{\mathrm{FH}}$, this paper will take the more conservative route, and consider only relative movements in the coefficient. The results reveal considerable fluctuation in the magnitude of $b^{\mathrm{FH}}$ over the long run. Relatively low values ("high mobility") are associated with the following periods: the 1880s, 1905-15 and the 1920s, and the 1980s 
(I exclude the 1860s which have few data points).

On reflection, I believe, the results, and the trends from period to period, can be reasonably interpreted. First, international capital market integration, as measured by $b^{\mathrm{FH}}$ for this admittedly small sample, has shown no marked trend over the last hundred or so years: we can say that, in this narrow sense, saving-investment disassociation has been no stronger in the 1980s for these countries than it was circa 1900. Second, the Feldstein-Horioka savings-retention coefficient $b^{\mathrm{FH}}$ has not evolved uniformly or monotonically over time. A story might be told as follows, considering Figure 2. Capital mobility was relatively high (low $b^{\mathrm{FH}}$ ) during the $1880 \mathrm{~s}$, when financial markets were engaged in a frenzy of foreign investment. The crash of the early 1890s brought this phase to a halt (higher $b^{\mathrm{FH}}$ ), and capital mobility diminished markedly. Gradually, closer to World War One, capital mobility again increased (falling $b^{\mathbf{F H}}$ ) in the last great foreign investment boom during the age of high imperialism, propelled largely by British capital flows (Edelstein 1982). This episode was halted by the war, but only temporarily, and, somewhat surprisingly, evidence of continued capital mobility is still apparent after World War One, right up to 1929 (falling $b^{\mathrm{FH}}$ ), a sign of easing capital mobility during the boom of the roaring twenties (Kindleberger 1986). The Great Depression ushered in a time of increased autarky (Temin 1989; Eichengreen 1990; Eichengreen 1992). This phase was associated with increased capital controls and other impediments to capital mobility (Nurkse 1944; Einzig 1935). The structural change is also reflected in other measures of capital mobility, marking the Depression as a watershed in international capital mobility (Taylor 1996; Taylor and Obstfeld 1996). The regime switch effectively limited international capital mobility for several decades (rising $b^{\mathrm{FH}}$ ), as capital controls persisted under Bretton Woods. The postwar period witnessed an era of relatively weak international capital mobility, only beginning to be overcome in the late 1970s and 1980s when $b^{\mathrm{FH}}$ begins to decline, albeit to a limited degree (Feldstein and Bacchetta 1991; Obstfeld 1994; Taylor 1994a). The evolution not only of the coefficient estimate of $b$, but also of other measures of fit based on $R^{2}$ and the $t$-ratio, follows a similar pattern, as can be seen clearly in Figure 2. Finally we may note the remarkable relationship between the results of the $\mathrm{FH}$ test and the historical patterns of institutional change, monetary experiments, and policy regimes. Note the dramatic, but not entirely unsurprising, correlation between periods of tight saving-investment correlation and periods of crisis: the fit of the regression is much stronger in the 1870 s and 1890s depressions, around 
World War One, during the Great Depression (with especially tight correlations), and again in the 1970s crisis (oil shocks, collpase of Bretton Woods, stagflation). This would be expected if autarkic policy responses and or just greater uncertainty in such episodes acted as barriers to the free movement of capital.

\subsection{Caveats}

Can the results on the FH test be taken at face value, especially given the numerous criticisms of this approach? In this brief sections I confront some potential problems.

First, let us note the difficulties with historical data on saving rates. These are constructed residually from estimates of investment and saving, using the identity $S / Y=I / Y+C A / Y$. There is little reason to expect that historical investment data ( $I$, usually from macroeconomic accounts) and current-account data ( $C A$, principally from trade records) will have correlated errors, but they certainly will have measurement error of some sort. Since, by construction, $I / Y$ appears on both sides of the $\mathrm{FH}$ regression, this will impart upward bias into the estimate of $b^{\mathrm{FH}}$. There is no way around this absent independent saving data, which we simply do not have. One check for bias arising from errors in variables is to run the reverse regression of $S / Y$ on $I / Y$ (Maddala 1977, 293). This regression estimates how much domestic investment demand spills into domestic saving and the result is also reported in Table $3{ }^{6}$ In theory, $\operatorname{plim}\left(\hat{b}_{S / Y, I / Y}\right)<b<\left(\operatorname{plim}\left(\hat{b}_{I / Y, S / Y}\right)\right)^{-1}$. In practice, the results are inconclusive and very confusing, at least before 1930 . However, after 1930 both regressions point to $b$ being very close to 1 , typically in the 0.8 to 1.2 range with standard errors around 0.1 to 0.2 . The small sample size is a weakness here, as the reverse regression method is only really helpful in large samples.

An alternative check to the reverse regression is to implement the $\mathrm{FH}$ test in a different form. The traditional test looks for a high correlation of $S / Y$ and $I / Y$. $\operatorname{Corr}(S / Y, I / Y)$ close to one implies near closure, close to zero implies a fully flexible current account. An alternative is to look at the relationship between our two truly observed data series, $C A$ and $I$ : a fully flexible current account with investment and saving independent and uncorre-

\footnotetext{
${ }^{6}$ I only report $b$ and its standard error, since in this bivariate regression, the $R^{2}$ and $t$ stay the same when regressor and regressand are interchanged.
} 
lated, $\operatorname{Corr}(S / Y, I / Y)=0$, would be equivalent to $\operatorname{Corr}(C A / Y, I / Y)=-1$; investment shocks would pass through fully into current account debits, as the economy absorbs capital directly from the "world market." Conversely, under a fixed, inflexible, near zero, or unresponsive current account we would expect $\operatorname{Corr}(C A / Y, I / Y)$ close to zero. This method now has eliminated the problem of correlated errors on left- and right-hand side variables - though it cannot, of course, like any OLS system, be guaranteed to be free of simple measurement errors in the right-hand side variable. The results are also shown in Table 3 and in Figure 3 for comparison with the traditional $\mathrm{FH}$ regression. The regression $(C A / Y)_{i}=a+b(I / Y)_{i}+u_{i}$ yields a $b$ estimate significant and negative before World War One for many periods, but rarely thereafter. In the $1880 \mathrm{~s}$, the coefficient approaches -0.6 and just before 1914 approaches -1.0 . This parallels our earlier account of the gold standard experience. However, after 1915 the coefficient is close to zero, and of low significance. Thus, this alternate measure confirms the belief that the pre-1914 gold standard was a period of relatively good capital mobility, but provides little evidence for pronounced market integration thereafter.

Notwithstanding the technical difficulties, the interpretation is not uncontroversial. The story told may seem to depart from conventional accounts. For example, the evidence of 1920 s capital mobility seems implausible given that World War One disrupted international capital markets and given the many qualitative interpretations of the decline in capital mobility during the collapse and fleeting restoration of the gold standard, and the disappearance of the "hegemonic" stability formerly provided by London and only half-heartedly emulated by New York. In the subsequent discussion of short-run capital mobility I will try to offer additional evidence that might provide some reasonable grounds for interpreting the new findings: there the evidence suggests that individual country experience showed considerable heterogeneity in the various eras, from pre-1914, to inter-war, to post-1945. If the short-run capital mobility results have any connection to long-run capital mobility properties, they might reasonably inform us that whilst some countries almost certainly did experience a tightening of savinginvestment correlation after 1914, still some others experience a loosening. In short, the evidence that follows suggests that capital-mobility experience has been marked by great variety across time and space, with some countries experiencing increased integration just when others experienced increased disintegration-whilst all along an "average" measure over the cross-section remained remarkably stable. 
However, a simple test of the FH approach offers one more motivation for a more flexible specification which admits cross-sectional heterogeneity. Specifically, we can implement the test proposed by Fujiki and Kitamura (1995), to see whether the implicit pooling in the FH approach is justified. In this test, we recognize that the conventional $\mathrm{FH}$ regression (equation 5) is in fact a form of panel "between" estimator. In detail, we may consider a time-series estimator

$$
(I / Y)_{i t}=a^{\mathrm{TS}}+b^{\mathrm{TS}}(S / Y)_{i t}+u_{i t}, i=\text { fixed, } t=1, \ldots, T
$$

a (true) cross-section estimator

$$
(I / Y)_{i t}=a^{\mathrm{CS}}+b^{\mathrm{CS}}(S / Y)_{i t}+u_{i t}, i=1, \ldots, N, t=\text { fixed }
$$

a between estimator

$$
{\overline{(I / Y)_{i}}}_{i}=a^{\text {betw }}+b^{\text {betw }}{\overline{(I / Y)_{i}}}_{i}+u_{i}, i=1, \ldots, N
$$

and a pooling estimator

$$
(I / Y)_{i t}=a^{\mathrm{pool}}+b^{\mathrm{pool}}(S / Y)_{i t}+u_{i t}, i=1, \ldots, N, t=1, \ldots, T .
$$

By inspection, the FH approach (equation 5) is not a "pure" cross-section estimator. By using time-averaged data it may escape some of the short-run cyclical variations which contaminate annual data at business-cycle frequencies, and this may be more pertinent for measuring "long-run" capital mobility (Obstfeld 1994). Does this averaging make a difference? To check, we can follow Sinn (1992) and report the true $b^{\mathrm{CS}}$, as above, using one-year "snapshots" of data throughout the whole sample. The results are shown in Table 4 and Figure 4. Focusing on the figure, however, it is clear that the time-averaging has not changed the qualitative result. Like $b^{\mathrm{FH}}$, Sinn's measure $b^{\mathrm{CS}}$ exhibits a structural jump in the 1930s; it is usually small and insignificant under the pre-1914 gold standard except for the 1890s; and it is large and significant after 1930, though declining in the $1960 \mathrm{~s}, 1970 \mathrm{~s}$, and 1980 , suggesting some mild and gradual improvements in capital mobility in the postwar period (as Sinn has shown).

In fact, the $\mathrm{FH}$ approach is a between estimator for 5- or 10-year samples, and $b^{\mathrm{FH}}=b^{\mathrm{pool}}$ as above. However, some simple and standard econometric algebra for panels demonstrates that the pooling estimator is a weighted sum 
of the time-series and between estimators. ${ }^{7}$ Thus, if we accept the between (FH) estimator, ought we to be willing to accept the pooling estimator? Is such pooling justified? This amounts to a test of the restricted pooling estimator against the unrestricted time-series estimator. A simple $F$-test proposed by Fujiki and Kitamura (1995) allows us to discriminate between the two, and thus explore the possibility of cross-section heterogeneity in the saving-investment relationship. The results of this test are also shown in Table 3, and in all cases the pooling restrictions are rejected at standard significance levels, in favor of individual-country time-series estimators.

Obviously more work is needed on the cross-section estimation in other respects. It would be desirable, given the evidence on heterogeneity, to introduce appropriate controls that might be necessary to alleviate potential omitted-variable bias in the Feldstein-Horioka estimation procedure. ${ }^{8}$ Efforts might also be made to construct long-run time series of measures of financial development, such as the ratio of financial assets to GDP, since such development almost certainly facilitated the mobilization of capital and might well have given simultaneous saving and investment incentives by reducing transaction costs. Such concerns remain the target of ongoing work. ${ }^{9}$

\footnotetext{
${ }^{7}$ Explicitly, following Fujiki and Kitamura (1995), $\hat{b}^{\text {pool }}=\theta \sum_{i=1}^{N} \hat{\delta}_{i} \hat{b}^{\text {TS }}+(1-\theta) \hat{b}^{\text {betw }}$, where $\theta=\frac{\sum_{i=1}^{N} W_{S I}(i)}{\sum_{i=1}^{N} W_{S S}(i)+N B_{s s}}, \hat{\delta}_{i}=\frac{W_{S S}(i)}{\sum_{i=1}^{N} w_{s s}(i)}, W_{S S}(i)=\sum_{t=1}^{T}\left((S / Y)_{i t}-\overline{(S / Y)_{i}}\right)^{2}$, $W_{S I}(i)=\sum_{t=1}^{T}\left((S / Y)_{i t}-{\overline{(S / Y)_{i}}}_{i}\right)\left((I / Y)_{i t}-{\overline{(I / Y)_{i}}}_{i}, B_{S S}(i)=\sum_{i=1}^{N}\left(\overline{(S / Y)_{i}}-\overline{(S / Y)}\right)^{2}\right.$, and $\overline{(S / Y)}=\frac{1}{N T} \sum_{i=1}^{N} \sum_{t=1}^{T}(S / Y)_{i t}$.

${ }^{8} \mathrm{~A}$ study by Taylor (1994a) discusses some especially important controls needed for a very wide (104 country) post-1950 sample, namely demographic structure, growth and relative prices. Tesar (1991) had previously emphasized the importance of controls for demographic structure. It will be almost surely impossible to extend relative price controls back to the nineteenth century, since in many cases we simply do not have the requisite aggregate demand disaggregation and price levels in extensive detail. However, it is reasonable to suppose that national income time-series and census records of population structure might allow us to control for serious potential biases arising from differential growth environments (high growth via productivity shocks might be associated with high saving and high investment) and differential demographic structures (an expansion in the working-age share of population might simultaneously raise derived investment demand and raise saving via dependency effects).

${ }^{9}$ Such variables have been shown to cloud the interpretation of the Feldstein-Horioka coefficient (Tesar 1991; Kose 1994; Taylor 1994a). In a historical setting, it has oft been argued that demographic structure and financial development might have played important and simultaneous roles as determinants of saving, investment and, hence, foreign lending (Green and Urquhart 1976; Edelstein 1982; Eichengreen 1990; Taylor and Williamson
} 
These findings caution against the loose characterization of capital mobility in cross-section samples assumed to be representative of the "world" capital market. Recent historical research in international labor market mobility has revealed evidence of marked segmentation in some cases (Williamson 1995). Similarly, it might be worth refining our nations of international capital mobility to allow for different market segments: groups of countries, not of uniform or stable membership over time, some of which have relatively open capital market characterizations, some relatively closed. The individual country time-series perspective allows us these nuances and it is to that analysis that we next turn.

\section{5 "Short-Run" Capital Mobility Since 1850: An Error Correction Model}

As already noted, an alternative approach to estimating the Feldstein-Horioka savings-retention coefficient is to employ time-series analysis for an individual country, with an estimating equation of the form 6 . However, for technical reasons, there is no reason to expect $b^{\mathrm{CS}}$ and $b^{T S}$ to bear any relation to each other since the time-series and cross-section properties of the estimators differ dramatically. Moreover, the natural interpretation of the two coefficients differs substantially - typically $b^{\mathrm{CS}}$ is considered an indicator of long-run international capital mobility in a sample group of countries, whereas $b^{T S}$ is seen as a measure of short-run, year-to-year international capital mobility in a single country (Obstfeld 1986; Obstfeld 1994).

The time-series estimation of the coefficient also raises additional concerns. Equation 6, if it is to be properly estimated, embodies an assumption of stationarity in the series $(I / Y)_{i t}$ and $(S / Y)_{i t}$. Such an assumption may indeed be valid, especially for short time frames. However, over longer horizons, several studies have cast doubt on the assumption that saving and investment rates are truly stationary.

1994). Eichengreen reports Goldsmith's data on the dramatic increase in the financial asset to GDP ratio in several countries in the nineteenth century, offering support for the view that such structural change in the operation of markets must be incorporated in any coherent analysis of long-run international capital market development. Kose has recently introduced such variables in an analysis of the Feldstein-Horioka results for the contemporary period using the variables constructed by King and Levine (Eichengreen 1990; King and Levine 1993; Kose 1994). 
This result will come as no surprise to economic historians: the notion of saving and investment shifts as important features of growth and structural transformation in the long run is embodied in many national histories, including the famous "grand traverse" described by the United States economy in the nineteenth century (Abramovitz and David 1973; David 1977). A similar upward shift in the investment rate has been documented in nineteenth century Britain (Crafts 1985, chapter 4, for example). The stationarity of some settler-economy saving and investment rate series could also be called into question based upon an examination of long-run trends in the Australian and Canadian data since 1870 (McLean 1994 illustrates the patterns). All of the above observations impinge on this analysis since all four countries are part of our sample. Of course, the same idea is seen elsewhere, and the proposition that a structural shift in the level of saving and investment relative to GDP represents a key transition was at the heart of Arthur Lewis's description of the development process:

The central problem in the theory of economic development is to understand the process by which a community which was previously saving and investing 4 or 5 per cent of its national income or less, converts itself into an economy where voluntary saving is running at about 12 to 15 per cent of national income or more. This is the central problem, because the central fact of economic development is rapid capital accumulation (including knowledge and skills with capital). We cannot explain any "industrial" revolution (as the economic historians pretend to do) until we can explain why saving increased relatively to national income. (Lewis 1954,155 )

We can use routine Dickey-Fuller tests to check on the stationarity of the series, and the results are shown in Table 2 for the series $(S / Y)_{i t},(I / Y)_{i t}$, and $(C A / Y)_{i t}$. The current-account ratio appears stationary in most cases, encouraging the view that it may be subject to equilibrium tendencies as theory suggests. However, the saving and investment series may not be stationary in all cases. Thus, the new strand of cointegration research into the properties of saving and investment correlations may have a particular resonance in long-run historical applications. It is this line of enquiry that will now be pursued.

The cointegration approach to the estimation of equation 6 has been much discussed in the literature, and the details need not be repeated at length 
here (Miller 1988; Leachman 1991; Vikøren 1991; Jansen and Schulze 1996). If the series $(S / Y)_{i t}$ and $(I / Y)_{i t}$ are nonstationary, but rather integrated, say $I(1)$, then 6 is improperly specified unless the series are cointegrated so that the error term $u_{i t}$ is still a stationary $I(0)$ series. A battery of standard diagnostic procedures may be used to test for this property of $u_{i t}$. In the case of cointegration, moreover, the Engle-Granger (1987) result shows that a two-step procedure can reveal an error-correction representation of 6 . The simplest such representation, commonly adopted in the literature, is the first-order error-correction model (ECM), written as follows (suppressing the index for country $i$ henceforth),

$$
\Delta(I / Y)_{t}=w_{0}+w_{1} \Delta(S / Y)_{t}+w_{2} z_{t-1}+u_{t}
$$

where $z_{t}=(I / Y)_{t}-\theta_{0}-\theta_{1}(S / Y)_{t}$ is the so-called error correction term, equal to the residual from the first-step time-series regression in levels,

$$
(I / Y)_{t}=\theta_{0}+\theta_{1}(S / Y)_{t}+z_{t}
$$

By a redefiniton of parameters, 10 may be rewritten as,

$$
\begin{aligned}
\Delta(I / Y)_{t}= & a^{\mathrm{ECM}}+b^{\mathrm{ECM}} \Delta(S / Y)_{t}+ \\
& c^{\mathrm{ECM}}\left((S / Y)_{t-1}-(I / Y)_{t-1}\right)+d^{\mathrm{ECM}}(S / Y)_{t-1}+u_{t}
\end{aligned}
$$

Following Jansen and Schulze (1996), I adopt 12 as a convenient estimating equation for implementing a well-specified test of the saving-investment correlation. It is immediately obvious that equation 12 embodies a longrun equilibrium relationship between saving and investment prescribed by theory, where, in the steady-state equilibrium (denoted ${ }^{*}$, where $\Delta(I / Y)_{t}=$ $\left.\Delta(S / Y)_{t}=0\right)$, the implied relationship in levels is given by $a^{\mathrm{ECM}}+c^{\mathrm{ECM}}\left((S / Y)^{*}-\right.$ $\left.(I / Y)^{*}\right)+d^{\mathrm{ECM}}(S / Y)^{*}=0 .{ }^{10}$ Parameter restrictions may be used to test various natural hypotheses concerning the nature of this long-run equilibrium: if $d^{\mathrm{ECM}}=0$ then the long-run equilibrium current account is equal to a constant, $C A^{*}=(S / Y)^{*}-(I / Y)^{*}=-a^{\mathrm{ECM}} / c^{\mathrm{ECM}}$; furthermore, if $a^{\mathrm{ECM}}=d^{\mathrm{ECM}}=0$, then this constant is zero.

It warrants mention that most other econometric specifications used in the literature on time-series estimation of the Feldstein-Horioka coefficient

\footnotetext{
${ }^{10}$ On average, considering the permanent level of saving and investment, we expect the difference between the present values of the two variables to be equal to initial wealth, assuming the usual transversality condition that no national Ponzi schemes are possible, whereby national assets holdings are bounded in the long run.
} 
also constitute special cases of 12 , and, hence, their validity may be tested by tests of parameter restrictions. The basic time series specification, which assumes no cointegration, and which has been considered by studies including Frankel (1992) and Obstfeld (1986; 1994), takes the form 6 corresponding to the restrictions $b^{\mathrm{ECM}}-d^{\mathrm{ECM}}=1$ and $c^{\mathrm{ECM}}=1$ in 12 . I will label this restriction $\mathrm{R} 1$. The differenced form of 6 , which admits no long run steady state, and which has been used by various studies (Obstfeld 1986; Feldstein and Bacchetta 1991; Obstfeld 1994, for example), takes the form

$$
\Delta(I / Y)_{t}=a^{\mathrm{DTS}}+b^{\mathrm{DTS}} \Delta(S / Y)_{t}+u_{t},
$$

corresponding to the restrictions $d^{\mathrm{ECM}}=c^{\mathrm{ECM}}=0$ in 12 . I will label this restriction $\mathrm{R} 2$. A third alternative specification is a partial adjustment form used by Feldstein and Bacchetta (1991) which assumes a long run equality of saving and investment, and which takes the form

$$
\Delta(I / Y)_{t}=a^{\mathrm{PA}}+b^{\mathrm{PA}}\left((S / Y)_{t-1}-(I / Y)_{t-1}\right)+u_{t}
$$

corresponding to the restrictions $d^{\mathrm{ECM}}=b^{\mathrm{ECM}}=0$ in 12 . I will label this restriction $\mathrm{R3}$. All these restrictions place certain prior constraints on the dynamic and (or) equilibrium specification, and since the general specification 12 subsumes such possibilities, it represents an appropriate starting point for empirical investigation. We should also remember that recent econometric advances suggest that the estimation of the error correction model 12 directly, without recourse to the two-step Engle-Granger procedure, provides a compact analytical methodology and a direct, and arguably more powerful, test for cointegration than the conventional tests such as Dickey-Fuller and Phillips-Perron. Following the test outlined by Kremers, Ericsson and Dolado (1992) and used by Jansen and Schulze (1996), we may interpret a hypothesis test of $c^{\mathrm{ECM}}$ being non-zero as equivalent to a test of cointegration. ${ }^{11}$

The coefficient $b^{\mathrm{ECM}}$ will have the natural interpretation: even given a long-run equilibrium relationship between saving and investment, $b^{\mathrm{ECM}}$ measures to what extent a temporary annual shock to domestic saving passes

\footnotetext{
${ }^{11} \mathrm{Kremers}$ et al. show that the $t$-statistic of $c^{\mathrm{ECM}}$ is asymptotically normal $N(0,1)$. Of course, when $c^{\mathrm{ECM}}$ and $d^{\mathrm{ECM}}$ are zero, equation 12 simplifies to look like equation 13 , the differenced form of 6 , which is then the analogous and appropriate estimating equation when $(S / Y)_{t}$ and $(I / Y)_{t}$ are $\mathrm{I}(1)$ but not cointegrated. Conversely, however, the presence of cointegration would imply that the simple differencing of 6 to produce an estimating equation 13 would yield a misspecified estimating equation: that is, an unjustified imposition of the restriction $c^{\mathrm{ECM}}=d^{\mathrm{ECM}}=0$ in the error-correction representation.
} 
through (fully? partially? not at all?) into domestic investment. In the present analysis, the specification 12 will be estimated for the long-run timeseries data for each country. The coefficient $c^{\mathrm{ECM}}$ also has a natural interpretation: it measures the speed of convergence of the system toward equilibrium. Converted into a "half-life" measure, this provides an indication of the sustainability of current-account disequilibria for each country in the sample period under study.

The availability of very long time series permits us to estimate the equation separately for different sample periods. I exogenously imposed "natural" break points at 1914, 1945 and 1973. This method will allow us to detect structural breaks in all the parameters, in particular the short-run savingsretention coefficient $b^{\mathrm{ECM}}$, and the speed of convergence $c^{\mathrm{ECM}}$. This is an appropriate test given the strong priors in the historical literature concerning the changes in international capital mobility from the pre-1914 and inter-war periods, to the two postwar periods, before-and-after the collapse of Bretton Woods. A restriction test may be applied to test for the stability of the regression coefficients in the long run, where, as an alternative, we pool all four time periods and impose non-varying coefficients from 1850 to 1992. I will label this restriction R4.

The specification is now complete and the various hypothesis tests established. The coefficient $b^{\mathrm{ECM}}$ is interpreted as the short-run savings-retention coefficient in the various subperiods examined. The size of the coefficient $c^{E C M}$ is a measure of the sustainability of current-account imbalances. The significance of the coefficient $c^{\mathrm{ECM}}$ is used as a test for cointegration. The coefficients $a^{\mathrm{ECM}}$ and $d^{\mathrm{ECM}}$ indicate the nature of the long-run saving-investment equilibrium. Various F-tests of restrictions (R1, R2, R3) compare the ECM specification 12 with restricted alternatives commonly used in the literature, and an F-test for structural stability (R4) detects whether the four-subperiod sample split is justified.

The results, presented by country, appear in Tables 5 and 6, and Figure 5. The evidence suggests a wealth of contrasts between individual country experiences with short-run international capital mobility over the last century or more. A discussion of the econometric specification in Table 5 is in order. In most cases the cointegration approach is justified, since the coefficient $c^{\mathrm{ECM}}$ is usually significant, and there is no country for which $c^{\mathrm{ECM}}$ is never significant. Frequently, the weakest significance is for the post-1972 sample, which might be attributed to small sample size. The restriction tests R1 through R3 usually fail, suggesting that in most circumstances the 
specification 12 dominates the alternatives commonly used in the literature. Again, the small post-1972 sample usually generates the weakest tests. The restriction test $R 4$ usually fails, indicating that the regression coefficients do not exhibit long-run stability, a result suggesting temporal heterogeneity in individual countries' capital mobility experience; the exceptions are Sweden and the United States, where the results are consistent with coefficients which do not vary across the four sample periods. In most cases (all but about a dozen cases out of 40 in the table), the implied long-run equilibrium saving-investment relationship is indeed characterized by the property that the steady-state current account $(C A / Y)^{*}=(S / Y)^{*}-(I / Y)^{*}$ equals a constant, as prescribed by theory (the restriction $d^{\mathrm{ECM}}=0$ holds); and in all those cases the constant appears to be not significantly different from zero (the restriction $a^{\mathrm{ECM}}=0$ also holds).

Concerning the short-run savings-retention coefficients $b^{\mathrm{ECM}}$ estimated in Table 2, we might turn to Figure 5 for a succinct presentation of the main short-run capital mobility trends revealed by this analysis. The countries are sorted alphabetically, with six in each chart for clarity. It appears that many countries exhibit a coefficient trend consistent with the notion of increasing capital mobility over time: the serious exceptions to this proposition are Argentina, Australia, Denmark and the United States. In the case of Argentina, the rising size and significance of the coefficient might be considered an intelligible result given the grossly simplified (but not entirely inaccurate) characterization of Argentina as a country with increasingly autarkic stance in external markets over the course of the century. The Danish result is of borderline significance, and this and the Australian result may be possibly due to the small sample size after 1974. In the case of the United States, the result is less puzzling, since it confirms earlier findings such as the large coefficient found by Frankel (1992) using levels and differences; the result is quite plausibly a "large country" aberration - since the U.S. is such a large player in world capital markets, shocks to saving rate might quite plausibly spill over into the world interest rate, and hence into domestic investment. All of these distinct country experiences certainly warrant further study. How robust are the results? How do they conform to qualitative evaluations of capital-market performance over time and the conventional historical treatments of national experience with international capital markets? Are there specific institutional or historical experiences that can explain the very different trends and peaks across countries?

The coefficient $c^{\mathrm{ECM}}$ also reveals interesting patterns of heterogeneity. For 
example, the countries with the most-sustainable current-account imbalances before 1914 were Argentina, Australia, Canada, and the United States-a result entirely consistent with the status of these four settler economies as the principal importers of British capital. A marked shift occurs after 1914 for this group. In the inter-war period, however, Germany stands out as a country facing sever financing constraints in the form of a very fast adjustment speed (exceeding one!): inflows were very quickly offset by countervailing outflows, and vice versa, reflecting the very unstable capital market of the time. Across all periods, the main financial centers, the U.K. and U.S., show relatively low speeds of convergence, as expected. After 1974, Norway shows a very sustainable deficit, a well-known consequence of oil discoveries.

We might also ponder to what extent the variety of country experience indicated by $b^{\mathrm{ECM}}$ and $c^{\mathrm{ECM}}$ can help us understand the fluctuations in the $b^{\mathrm{CS}}$ (or $b^{F H}$ ) measure of long-run capital mobility discussed earlier in this paper. In a trivial sense, the long-run is just a concatenation of short-runs, so although the methodologies may have different natural interpretations they may helpfully inform each other. A natural question to ask is whether the savings-retention coefficient differs in the long and short run. For example, in the ten-country sample, the average value of $b^{\mathrm{ECM}}$ in Table 5, averaged across countries, by period, is as shown in Table 6: rising from 0.48 before 1914 to 0.59 in the inter-war period, and continuing to rise to 0.61 during Bretton Woods and to 0.69 in the recent float. Looking at $c^{\mathrm{ECM}}$ we see an initial rise in the inter-war period from 0.28 to 0.47 , then a leveling off after 1946 at 0.55 , falling after 1974 to 0.39 .

We may view these coefficient populations as a draw from a heterogeneous panel of countries and examine the distribution of coefficients for any changes across samples. Obviously, it cannot be argued that any subsequent period has improved on the degree of capital mobility seen before 1914 . The shortrun pass-through coefficient $b^{\mathrm{ECM}}$ is always higher in later periods. However, in terms of sustainability of capital flows measured by $c^{\mathrm{ECM}}$, some improvement is seen after the setbacks of the inter-war period. The half-life duration is cut almost in half after 1914, but by the 1970s and 1980s it is rising once again.

The findings are fairly consistent with the conventional wisdom: capital mobility has changed little over the long run, but suffered a setback in the inter-war period. If this bears any relation at all to average long-run capital mobility in the ten countries we would have some framework for interpreting the cross-sectional results: the constancy of $b^{\mathrm{CS}}$ over time may not reflect so 
much a lack of global capital market integration, but the sometime entrance and departure of various countries from the "club" of well-integrated countries, as evidenced by the very different paths taken by $b^{\mathrm{ECM}}$ and $c^{\mathrm{ECM}}$ in different countries. Here, then, the time-series results offer some perspective on the evolving segmentation in the world capital market, and possibly some insight into the "puzzling" persistence of a high $b^{\mathrm{CS}}$ over time.

Another averaging experiment produces another reasonable result, where we view the coefficients as a draw from a heterogeneous panel of countries. The average value of $b^{\mathrm{FH}}$ from Table 3 is about 0.7 for the sample over all periods ( 0.70 for 10-year periods in the top panel; 0.69 for 5 -year periods in the bottom panel); the average value of $b^{\mathrm{ECM}}$ from Table 6 is about 0.6 for the sample over all periods ( 0.59 for for the four subperiods). By this reckoning, the average "long-run savings-retention" coefficient $(0.7)$ has been higher than the "short-run savings-retention" coefficient (0.6) over the last century or more, suggesting a plausible interpretation: that capital mobility has always been greater in the short run than in the long. Such is a result we would expect given the shorter time-horizon and commensurately lower costs and risks of temporary shifts in national assets across national boundaries, and also given the likelihood that borrowing constraints bind less severely in an "incremental fashion" in the short run (for example, the need for a temporary funding facility through a current account deficit to deal with transitory circumstances) compared with the manner in which they bind in the full portfolio sense in the long run (as in the persistent running of current account imbalances entailing a structural shift asset distribution). This view also accords with conventional wisdom, and the view that "hot money" flows of short-term capital have always been more mobile than the "cold-money" flows of long-term capital.

\section{Conclusion}

This study has presented a number of new results using one widely applied criterion for short- and long-run capital mobility, the Feldstein-Horioka test. The results offer some support for the conventional qualitative accounts of long-run developments in the international capital market. In cross section, the results show a marked tightening of the saving-investment correlation in periods of global economic crisis, symptomatic of diminishing capital mobility in such periods. In time series the results show considerable heterogeneity 
in individual country experience that warrants further study. The study advances debate by refining our "yardstick" of measurement for the FeldsteinHorioka coefficient; since the coefficient embodies no absolute standard, its interpretation must rest on comparative studies of the coefficient and its variation across time and space. Thus, the estimates of cross-section and time-series (error-correction) coefficients for a ten-country sample over almost 150 years offer a sounder basis for historical interpretation of the long-run evolution of international capital mobility.

Nonetheless, the work offers scope for further research to address remaining concerns, some of them intrinsic to the Feldstein-Horioka methodology, some of them a consequence of the incompleteness of our historical data sources. Concerning data, much remains to be explored in further work. It would be desirable to extend the sample to more countries, say 15 or 20 in total, and a more detailed examination of other national accounts data might yield further sample points, although the maximum cross-section sample of currently reliable time-series sources before 1914 is almost surely bounded below 20. In addition, the cross-section heterogeneity will prompt a search for additional control variables. Such work is planned for the future.

For the present the results offer a consistent quantitative perspective on the long-run evolution of international capital market integration in the nineteenth and twentieth centuries. For interpretative purposes I have been strict on the structure of the analysis: for meaningful results, care has to be taken to gather data in a uniform way over time for all countries, and apply exactly the same methodology over time and space in the estimations. We have previously seen various cross-section "snapshots" of the saving-investment correlations: for example, in the studies of Obstfeld (1986; 1994), Bayoumi (1989), Zevin (1992), and Eichengreen (1990). We have also seen various studies that have used individual country time-series over the very long run, as in Frankel's (1992) study of United States experience. Others, like Zevin (1992), have appropriated these quantity-based criteria and melded them with price-based criteria for market integration. ${ }^{12}$

\footnotetext{
${ }^{12}$ To complement the present paper, then, extensive use of price criteria would be a desirable direction for research on the period and countries covered here -but the difficulties are considerable. As Obstfeld (1994) notes, the price approach requires the study of identical financial instruments in different markets (e.g., the offshore-onshore price differential); in contrast, the study of other non-commensurate asset prices, such as bonds prices or interest rates, can be wholly misleading. The historical use of asset price criteria for international capital market integration has been limited, but successful, where the data
} 
Presently, the quantity-based criteria remain a staple approach for historical studies, and, as this paper tries to show, might still reveal provocative insights. The findings also have broader implications for the debate over globalization and convergence (Williamson 1996). Abramovitz (1986) and Baumol (1986) noted the long-run patterns of convergence in income per capita in a cross-section of countries, using the historical national income data of Maddison (1991 and his previous studies). Abramovitz noted that not only technological convergence, but also "trade and its rivalries" might have played a part in this historical convergence process, the latter including factor mobility. The convergence findings were corroborated by Williamson (1995) for real wages, and these patterns may be linked to the evolution and integration of global labor and commodity markets (see Williamson 1996). Of course, there may be substantial complementarities between labor and capital mobility, as in the theory of factor price convergence, and as historical experience shows (O'Rourke, Taylor, and Williamson 1996).

The present paper complements a larger literature on factor mobility, and can help us gauge the importance long-run capital mobility to the historical convergence process. The inter-war period, and the Great Depression in particular, are highlighted as a major structural shift in capital mobility, as other studies based on interest rate deviations, saving-investment correlations, and other quantitative criteria are beginning to suggest. ${ }^{13}$

permitted (Neal 1990). But the collection of a 120-year panel data set on offshore-onshore prices for 10 or more countries remains a distant target.

${ }^{13}$ See Eichengreen (1990); Lothian (1995); Taylor (1996); Obstfeld and Taylor (1996). 


\section{Data Appendix}

The data used in the paper consists of annual saving and investment rates for each of the 12 countries in the sample. Data was collected for every available year between 1850 and 1992. The data is shown in Appendix Tables 1 and 2, with the following abbreviations used for each country:
ARG Argentina
AUS Australia
CAN Canada
DNK Denmark
FRA France
DEU Germany
ITA Italy
JPN Japan
NOR Norway
SWE Sweden
GBR United Kingdom
USA United States

1850-1914: The investment rate measure $(I / Y)_{t}$ is the ratio of gross investment $I_{t}$ to national income $Y_{t}$ at current local prices; the saving rate $(S / Y)_{t}$ was usually calculated implicitly, via the current account identity, as the investment rate $(I / Y)_{t}$ plus the ratio of the current account $C A_{t}$ to national income: $(I / Y)_{t}=I_{t} / Y_{t},(S / Y) t=\left(I_{t} / Y_{t}\right)+\left(C A_{t} / Y_{t}\right)$. Except as otherwise indicated this data is taken from Jones and Obstfeld (1994), who revised the standard sources to correct for flows of gold and changes in stocks.

1915-1959: The investment and saving rates are defines as above: saving rates are still calculated residually from the current account. Except as otherwise indicated this data is taken from Mitchell $(1983,1992)$ using his national income and overall current balance series at current prices. The overall current balance series are converted from U.S dollars using his exchange rate series as necessary.

1960-1992: Estimates of gross domestic saving, gross domestic investment, and gross domestic saving at current prices from World Bank (1994).

\section{Argentina}

1885-1913: Nominal investment constructed from Di Tella and Zymelman's (1967) real investment index and Della Paolera's (1988) price level, linked to the IEERAL (1986) value for 1913. Nominal income from Della Paolera's (1988) output index and price level, linked to the IEERAL (1986) value for 1913 (similar results obtain using Cortés Conde's (1994) estimates). Exports, imports, and debt service from Williams (1920), Ford (1962), and Della Paolera (1988) in gold pesos, converted to 
paper pesos using Della Paolera's (1988) price series. Missing data on debt service for 1892-94 approximated at total balance of borrowings according to Williams plus $\$ 7$ million gold pesos, the approximate annual new borrowings (very small) in the Baring crisis years 1891-95. Missing data on debt service between Williams' 1900 and Ford's 1912 observations (the latter from Phelps 1938)) is approximated by interpolation along an exponential trend, since there were no defaults in this period, and debt probably grew relatively smoothly.

1914-59: Investment, and the current account (exports and imports) in current prices from IEERAL (1986).

\section{Australia}

1861-1988: Derived from the previously compiled estimates of N. Butlin (1962), M. Butlin (1977), and McLean (1994), as described in Taylor and Williamson (1994).

\section{Canada}

1870-1984: Investment rate and residually-calculated saving rate from Urquhart (1988).

\section{France}

1922-38: The overall current balance is taken from Mitchell, but is converted from gold francs to (current) paper france using series on the value of the franc relative to parity taken from the League of Nations, Annuaire Statistique (various issues). The investment share of national income is taken from Carré, Dubois, and Malinvaud (1975).

\section{Germany}

1925-35, 1950-59: Based on Mitchell, but refers to West Germany only after 1945. Before 1945, Mitchell gives data on net capital formation. This is inflated to an approximation of gross capital formation using an assumed capital-output ratio of 3 and an assumed depreciation rate of $3 \%$. 


\section{References}

Abramovitz, M. "Catching Up, Forging Ahead, and Falling Behind." Journal of Economic History 46 (June 1986): 385-406.

Abramovitz, M., and P. A. David. "Reinterpreting American Economic Growth: Parables and Realities." American Economic Review 63 (May 1973): 428-37.

Baumol, W. "Productivity Growth, Convergence and Welfare: What the LongRun Data Show." American Economic Review 76 (December 1986): 1072-85.

Bayoumi, T. "Saving-Investment Correlations: Immobile Capital, Government Policy or Endogenous Behavior?" IMF Working Paper no. 89/66, Washington, D.C., August 1989.

Butlin, M. W. "A Preliminary Annual Database 1900/01 to 1973/74." Research Discussion Paper no. 7701, Reserve Bank of Australia, Canberra, May 1977.

Butlin, N. G. Australian Domestic Product, Investment and Foreign Borrowing 1861-1938/39. Cambridge: Cambridge University Press, 1962.

Carré, J.-J., P. Dubois, and P. Malinvaud. French Economic Growth. Translated by John P. Hatfield. Stanford, Calif.: Stanford University Press, 1975.

Cortés Conde, R. "Estimaciones del PBI en la Argentina 1875-1935." Ciclos de seminarios no. 3/94, Departamento de Economía, Universidad de San Andrés, 1994.

Crafts, N. F. R. British Economic Growth during the Industrial Revolution. Oxford: Clarendon Press, 1985.

David, P. A. "Invention and Accumulation in America's Economic Growth: A Nineteenth-Century Parable." In International Organization, National Policies and Economic Development, edited by K. Brunner and A. Metzler. Amsterdam: North Holland, 1977.

Della Paolera, G. "How the Argentine Economy Performed During the International Gold Standard: A Reexamination." Ph. D. dissertation, University of Chicago, December 1988.

Díaz-Alejandro, C. F. Essays on the Economic History of the Argentine Republic. New Haven, Conn.: Yale University Press, 1970.

Di Tella, G., and M. Zymelman. Las etapas del desarrollo económico argentino. Buenos Aires: Editorial Universitaria de Buenos Aires, 1967.

Dornbusch, R. "Comment on Martin Feldstein and Phillipe Bacchetta." In $\mathrm{Na}$ tional Saving and Economic Performance, edited by B. D. Bernheim and J. B. Shoven. Chicago: University of Chicago Press, 1991.

Edelstein, M. Overseas Investment in the Age of High Imperialism. New York: 
Columbia University Press, 1982.

Eichengreen, B. "Trends and Cycles in Foreign Lending." In Capital Flows in the World Economy, edited by H. Siebert. Tübingen: Mohr, 1990.

Eichengreen, B. Golden Fetters. Oxford: Oxford University Press, 1992.

Engle, R., and C. Granger. "Cointegration and Error Correction: Representation, Estimation and Testing." Econometrica 55 (1987): 251-276.

Feldstein, M., and P. Bacchetta. "National Savings and International Investment." In National Saving and Economic Performance, edited by B. D. Bernheim and J. B. Shoven. Chicago: University of Chicago Press, 1991.

Feldstein, M., and C. Horioka. "Domestic Saving and International Capital Flows." Economic Journal 90 (June 1980): 314-29.

Ford, A. G. The Gold Standard, 1880-1914: Britain and Argentina. Oxford: Clarendon Press, 1962.

Frankel, J. A. "Quantifying International Capital Mobility in the 1980s." In $\mathrm{Na}$ tional Saving and Economic Performance, edited by B. D. Bernheim and J. B. Shoven. Chicago: University of Chicago Press, 1991.

Frankel, J. A. "Measuring International Capital Mobility: A Review." American Economic Review 82 (May 1992): 197-202.

Fujiki, H., and Y. Kitamura. "Feldstein-Horioka Paradoz Revisited." Bank of Japan Monetary and Economic Studies 13 (July 1995): 1-15.

Green, A., and M. C. Urquhart. "Factor and Commodity Flows in the International Economy of 1870-1914: A Multi-Country View." Bank of Japan Monetary and Economic Studies 36 (March 1976): 217-52.

IEERAL (Instituto de Estudios Económicos sobre la Realidad Argentina y Latinoamericana). "Estadísticas de la evolución económica de Argentina 1913-1984." Estudios 9 (July/September 1986): 103-184.

Jansen, W. J., and G. G. Schulze. "Theory-Based Measurement of the SavingInvestment Correlation with an Application to Norway." Economic Inquiry 34 (January 1996): 116-132.

Jones, M. T., and M. Obstfeld. "Saving and Investment Under the Gold Standard." University of California at Berkeley, November 1994. Photocopy.

Kindleberger, C. P. The World in Depression, 1929-1939. Berkeley: University of California Press, 1986.

King, R. G., and R. Levine. "Finance, Entrepreneurship, and Growth." Journal of Monetary Economics 32 (1993): 513-42.

Kose, M. A. "Financial Development and Saving-Investment Correlations." Uni- 
versity of Iowa, November 1994. Photocopy.

Kremers, J., N. Ericsson, and J. Dolado. "The Power of Cointegration Tests." Oxford Bulletin of Economics and Statistics 54 (1992): 325-348.

Leachman, L. "Saving, Investment and Capital Mobility among OECD Countries." Open Economies Review 2 (1991): 137-63.

Lewis, W. A. "Economic Development with Unlimited Supplies of Labour." The Manchester School 22 (May 1954): 139-91.

Lothian, J. R. "Capital Market Integration and Exchange-Rate Regimes in Historical Perspective." Fordham University, December 1995. Photocopy.

Maddala, G. S. Econometrics. New York: McGraw-Hill, 1977.

Maddison, A. Dynamic Forces in Capitalist Development: A Long-Run Comparative View. Oxford: Oxford University Press, 1991.

McLean, I. W. "Saving in Settler Economies: Australian and North American Comparisons." Explorations in Economic History 31 (October 1994): 432-52.

Miller, S. "Are Saving and Investment Cointegrated?" Economic Letters 27 (1988): 31-34.

Mitchell, B. R. International Historical Statistics: The Americas and Australasia. Detroit: Gale Research, 1983.

Mitchell, B. R. International Historical Statistics: Europe, 1750-1988. New York: Stockton Press, 1992.

Neal, L. The Rise of Financial Capitalism: International Capital Markets in the Age of Reason. Cambridge: Cambridge University Press, 1990.

Obstfeld, M. "Capital Mobility in the World Economy: Theory and Measurement." Carnegie-Rochester Conference Series on Public Policy no. 24, 1986.

Obstfeld, M. "Comment on Frankel." In National Saving and Economic Performance, edited by B. D. Bernheim and J. B. Shoven. Chicago: University of Chicago Press, 1991.

Obstfeld, M. "International Capital Mobility in the 1990s." International Finance Discussion Papers no. 472, Board of Governors of the Federal Reserve System, Washington, D.C., June 1994.

Obstfeld, M., and A. M. Taylor. "International Capital Market Integration in the Long Run: The Great Depression as a Watershed." University of California at Berkeley, 1996. Photocopy.

O'Rourke, K. H., A. M. Taylor, and J. G. Williamson. "Factor Price Convergence in the Late Nineteenth Century." International Economic Review (1996). Forthcoming. 
Phelps, V. L. The International Economic Position of Argentina. Philadelphia: University of Pennsylvania Press, 1938.

Sinn, S. "Saving-Investment Correlations and Capital Mobility: On the Evidence from Annual Data." Economic Journal 102 (September 1992): 1171-83.

Summers, L. H. "Tax Policy and International Competitiveness." In International Aspects of Financial Policies, edited by J. Frenkel. Chicago: University of Chicago Press, 1988.

Taylor, A. M. "External Dependence, Demographic Burdens and Argentine Economic Decline After the Belle Époque." Journal of Economic History 52 (December 1992): 907-36.

Taylor, A. M. "Domestic Saving and International Capital Flows Reconsidered." Working Paper Series no. 4892, National Bureau of Economic Research, 1994a.

Taylor, A. M. "Tres fases del crecimiento económico argentino." Revista de Historia Económica 12 (Fall 1994b): 649-83.

Taylor, A. M. "International Capital Mobility in History: Purchasing-Power Parity in the Long Run." Working Paper Series, National Bureau of Economic Research, August 1996. Forthcoming.

Taylor, A. M., and J. G. Williamson. "Capital Flows to the New World as an Intergenerational Transfer." Journal of Political Economy 102 (April 1994): 348371.

Temin, P. Lessons from The Great Depression. Cambridge, Mass.: MIT Press, 1989.

Tesar, L. L. "Savings, Investment and International Capital Flows." Journal of International Economics 31 (August 1991): 55-78.

Urquhart, M. C. "Canadian Economic Growth 1870-1980." Discussion Paper no. 734, Institute for Economic Research, Queen's University, Kingston, Ontario, 1988.

Vikøren, B. "The Saving-Investment Correlation in the Short and in the Long Run." Working Paper no. 91/7, Norges Bank, 1991.

Williams, J. H. Argentine International Trade Under Inconvertible Paper Currency, 1880-1900. Cambridge: Harvard University Press, 1920.

Williamson, J. G. "The Evolution of Global Labor Markets since 1830: Background Evidence and Hypotheses." Explorations in Economic History 32 (April 1995): 141-96.

Williamson, J. G. "Globalization, Convergence, and History." Journal of Economic History 56 (June 1996): 277-306.

World Bank. World Data 1994: World Bank Indicators on CD-ROM. Washington, D.C.: The World Bank, 1994. 
Zevin, R. B. "Are World Financial Markets More Open? If So, Why and With What Effects?" In Financial Openness and National Autonomy : Opportunities and Constraints, edited by T. Banuri and J. B. Schor. Oxford: Clarendon Press, 1992. 
Table 1

Current Account Relative to GDP:

Summary Statistics

\begin{tabular}{lrcc} 
Period & $N$ & Variance(CAY) & Mean(|CAY $\mid)$ \\
\hline $1870-1874$ & 10 & .00148 & .02951 \\
$1875-1879$ & 10 & .00102 & .02662 \\
$1880-1884$ & 10 & .00154 & .03220 \\
$1885-1889$ & 12 & .00324 & .04581 \\
$1890-1894$ & 12 & .00173 & .03442 \\
$1895-1899$ & 12 & .00108 & .03236 \\
$1900-1904$ & 12 & .00077 & .02569 \\
$1905-1909$ & 12 & .00160 & .03501 \\
$1910-1914$ & 12 & .00262 & .03786 \\
$1915-1919$ & 9 & .00415 & .05539 \\
$1920-1924$ & 11 & .00202 & .03973 \\
$1925-1929$ & 12 & .00118 & .02461 \\
$1930-1934$ & 12 & .00013 & .01710 \\
$1935-1939$ & 12 & .00022 & .01414 \\
$1940-1944$ & 9 & .00160 & .03097 \\
$1945-1949$ & 11 & .00125 & .03427 \\
$1950-1954$ & 12 & .00010 & .01770 \\
$1955-1959$ & 12 & .00024 & .01551 \\
$1960-1964$ & 12 & .00021 & .01345 \\
$1965-1969$ & 12 & .00022 & .01327 \\
$1970-1974$ & 12 & .00016 & .01402 \\
$1975-1979$ & 12 & .00044 & .01878 \\
$1980-1984$ & 12 & .00058 & .01958 \\
$1985-1989$ & 12 & .00056 & .02316 \\
\hline & & &
\end{tabular}

Notes:

Mean and variance calculated for cross section in each period. See text.

Sources:

See data appendix. 
Table 2

Samples and Unit Root Tests

\begin{tabular}{lllll} 
& & \multicolumn{3}{c}{ Dickey-Fuller $t$} \\
\cline { 3 - 5 } Country & Observations & $\mathrm{S} / \mathrm{Y}$ & $\mathrm{I} /$ & $\mathrm{CA} Y$ \\
\hline Argentina & $1885-1992$ & -3.02 & -1.98 & -4.66 \\
Australia & $1861-1992$ & -3.15 & -3.57 & -5.89 \\
Canada & $1870-1992$ & -2.54 & -2.26 & -2.70 \\
Denmark & $1874-1914,1921-1992$ & -1.89 & -1.99 & -3.92 \\
France & $1850-1913,1922-1938,1949-1992$ & -2.06 & -2.19 & -5.55 \\
Germany & $1860-1913,1925-1935,1950-1992$ & -1.57 & -2.25 & -4.01 \\
Italy & $1861-1992$ & -3.05 & -3.29 & -3.64 \\
Japan & $1885-1944,1946-1992$ & -1.60 & -1.58 & -4.53 \\
Norway & $1865-1939,1946-1992$ & -2.57 & -2.67 & -4.10 \\
Sweden & $1861-1992$ & -2.70 & -2.23 & -4.79 \\
U.K. & $1850-1992$ & -3.31 & -2.52 & -3.24 \\
U.S.A. & $1874-1992$ & -2.66 & -2.53 & -3.05 \\
\hline
\end{tabular}

Notes and sources:

See text. The critical values for the Dickey-Fuller t-test when $N=100$ :

$$
\begin{array}{ll}
p=0.10 & t=-2.58 \\
p=0.05 & t=-2.89 \\
p=0.01 & t=-3.51
\end{array}
$$

Sources:

See data appendix. 
Table 3

Feldstein-Horioka and Related Tests

\begin{tabular}{|c|c|c|c|c|c|c|c|}
\hline & \multirow[b]{2}{*}{$\mathrm{N}$} & \multicolumn{4}{|c|}{$\begin{array}{c}(I / Y)= \\
a+b(S / Y)+e\end{array}$} & \multicolumn{2}{|c|}{$\begin{array}{c}(S / Y)= \\
a+b(I / Y)+e\end{array}$} \\
\hline & & $\mathrm{A}$ sq. & $\mathrm{b}$ & $t$ & se & $b$ & se \\
\hline $1860-1869$ & 8 & .02 & 0.12 & 0.40 & 0.31 & 0.02 & 0.52 \\
\hline $1870-1879$ & 10 & .36 & 0.60 & 2.12 & 0.28 & 0.36 & 0.28 \\
\hline $1880-1889$ & 11 & .14 & 0.38 & 1.25 & 0.31 & 0.14 & 0.31 \\
\hline 1890-1899 & 12 & .60 & 0.58 & 3.89 & 0.15 & 0.60 & 0.26 \\
\hline $1900-1909$ & 12 & .43 & 0.72 & 2.78 & 0.26 & 0.43 & 0.22 \\
\hline $1910-1919$ & 12 & .58 & 0.72 & 3.73 & 0.19 & 0.58 & 0.22 \\
\hline $1920-1929$ & 12 & .44 & 0.48 & 2.83 & 0.17 & 0.44 & 0.32 \\
\hline 1930-1939 & 12 & .88 & 0.90 & 8.91 & 0.10 & 0.88 & 0.11 \\
\hline $1940-1949$ & 12 & .85 & 1.02 & 7.82 & 0.13 & 0.85 & 0.11 \\
\hline $1950-1959$ & 12 & .94 & 1.01 & 13.05 & 0.08 & 0.94 & 0.07 \\
\hline 1960-1969 & 12 & .92 & 0.92 & 10.75 & 0.09 & 0.92 & 0.09 \\
\hline $1970-1979$ & 12 & .91 & 0.92 & 10.44 & 0.09 & 0.91 & 0.09 \\
\hline $1980-1989$ & 12 & .79 & 0.71 & 6.24 & 0.11 & 0.79 & 0.18 \\
\hline $1860-1864$ & 6 & .10 & 0.14 & 0.67 & 0.22 & 0.10 & 1.03 \\
\hline $1865-1869$ & 7 & .16 & 0.26 & 0.99 & 0.27 & 0.16 & 0.62 \\
\hline $1870-1874$ & 10 & .24 & 0.49 & 1.63 & 0.31 & 0.24 & 0.31 \\
\hline $1875-1879$ & 10 & .41 & 0.75 & 2.38 & 0.31 & 0.41 & 0.23 \\
\hline $1880-1884$ & 10 & .24 & 0.52 & 1.61 & 0.33 & 0.24 & 0.29 \\
\hline 1885-1889 & 12 & .14 & 0.27 & 1.30 & 0.21 & 0.14 & 0.40 \\
\hline $1890-1894$ & 12 & .47 & 0.53 & 3.02 & 0.18 & 0.47 & 0.30 \\
\hline $1895-1899$ & 12 & .65 & 0.64 & 4.36 & 0.15 & 0.65 & 0.23 \\
\hline $1900-1904$ & 12 & .61 & 0.74 & 3.99 & 0.19 & 0.61 & 0.21 \\
\hline $1905-1909$ & 12 & .27 & 0.66 & 1.93 & 0.34 & 0.27 & 0.21 \\
\hline $1910-1914$ & 12 & .15 & 0.72 & 1.35 & 0.54 & 0.15 & 0.16 \\
\hline $1915-1919$ & 9 & .75 & 0.52 & 4.63 & 0.11 & 0.75 & 0.31 \\
\hline $1920-1924$ & 11 & .36 & 0.49 & 2.28 & 0.21 & 0.36 & 0.33 \\
\hline 1925-1929 & 12 & .50 & 0.47 & 3.18 & 0.15 & 0.50 & 0.33 \\
\hline $1930-1934$ & 12 & .93 & 1.00 & 11.83 & 0.08 & 0.93 & 0.08 \\
\hline $1935-1939$ & 12 & .87 & 0.97 & 8.26 & 0.12 & 0.87 & 0.11 \\
\hline $1940-1944$ & 9 & .73 & 0.62 & 4.45 & 0.14 & 0.73 & 0.26 \\
\hline $1945-1949$ & 11 & .78 & 1.13 & 5.64 & 0.20 & 0.78 & 0.12 \\
\hline $1950-1954$ & 12 & .97 & 1.04 & 18.64 & 0.06 & 0.97 & 0.05 \\
\hline $1955-1959$ & 12 & .90 & 0.96 & 9.60 & 0.10 & 0.90 & 0.10 \\
\hline $1960-1964$ & 12 & .90 & 0.96 & 9.68 & 0.10 & 0.90 & 0.10 \\
\hline $1965-1969$ & 12 & .88 & 0.88 & 8.72 & 0.10 & 0.88 & 0.11 \\
\hline $1970-1974$ & 12 & .94 & 0.90 & 12.54 & 0.07 & 0.94 & 0.08 \\
\hline $1975-1979$ & 12 & .79 & 0.87 & 6.14 & 0.14 & 0.79 & 0.15 \\
\hline $1980-1984$ & 12 & .76 & 0.69 & 5.78 & 0.12 & 0.76 & 0.19 \\
\hline 1985-1989 & 12 & .70 & 0.68 & 4.92 & 0.14 & 0.70 & 0.21 \\
\hline
\end{tabular}


Table 3 (contlnued)

Feldstein-Horioka and Related Tests

\begin{tabular}{|c|c|c|c|c|c|c|c|}
\hline & \multicolumn{4}{|c|}{$\begin{array}{c}(C A Y)= \\
a+b(I Y)+e\end{array}$} & \multicolumn{3}{|c|}{$\begin{array}{c}\text { Fujiki-Kitamura } \\
\text { Pooling Test }\end{array}$} \\
\hline & R sq. & b & $t$ & se & $\overline{F \text {-value }}$ & & alue \\
\hline $1860-1869$ & .27 & -0.78 & -1.50 & 0.52 & $F(14,48)=$ & 641.05 & .00 \\
\hline $1870-1879$ & .20 & -0.40 & -1.43 & 0.28 & $F(18,72)=$ & 12.59 & .00 \\
\hline $1880-1889$ & .31 & -0.61 & -2.02 & 0.31 & $F(20,88)=$ & 46.31 & .00 \\
\hline $1890-1899$ & .00 & 0.02 & 0.10 & 0.26 & $F(20,98)=$ & 15.48 & .00 \\
\hline $1900-1909$ & .25 & -0.40 & -1.86 & 0.22 & $F(20,98)=$ & 16.96 & .00 \\
\hline $1910-1919$ & .07 & -0.19 & -0.91 & 0.22 & $F(20,81)=$ & 7.04 & .00 \\
\hline $1920-1929$ & .00 & -0.08 & -0.27 & 0.32 & $F(20,90)=$ & 9.91 & .00 \\
\hline $1930-1939$ & .00 & -0.01 & -0.14 & 0.11 & $F(20,93)=$ & 5.73 & .00 \\
\hline $1940-1949$ & .18 & -0.16 & -1.52 & 0.11 & $F(17,75)=$ & 9.94 & .00 \\
\hline $1950-1959$ & .08 & -0.06 & -0.94 & 0.07 & $F(20,98)=$ & 10.88 & .00 \\
\hline $1960-1969$ & .00 & 0.00 & -0.08 & 0.09 & $F(20,98)=$ & 8.16 & .00 \\
\hline $1970-1979$ & .00 & 0.00 & -0.10 & 0.09 & $F(20,98)=$ & 7.70 & .00 \\
\hline 1980-1989 & .04 & 0.11 & 0.65 & 0.18 & $F(20,98)=$ & 9.91 & .00 \\
\hline $1860-1864$ & .02 & -0.30 & -0.29 & 1.03 & $F(12,15)=$ & 225.63 & .00 \\
\hline $1865-1869$ & .07 & -0.38 & -0.62 & 0.62 & $F(14,21)=$ & 465.84 & .00 \\
\hline $1870-1874$ & .25 & -0.50 & -1.63 & 0.31 & $F(17,24)=$ & 7.99 & .00 \\
\hline $1875-1879$ & .31 & -0.44 & -1.92 & 0.23 & $F(18,30)=$ & 19.06 & .00 \\
\hline $1880-1884$ & .29 & -0.53 & -1.83 & 0.29 & $F(18,30)=$ & 35.79 & .00 \\
\hline $1885-1889$ & .12 & -0.47 & -1.19 & 0.40 & $F(20,38)=$ & 57.74 & .00 \\
\hline $1890-1894$ & .01 & -0.10 & -0.34 & 0.30 & $F(20,38)=$ & 9.98 & .00 \\
\hline $1895-1899$ & .00 & 0.01 & 0.07 & 0.23 & $F(20,38)=$ & 12.00 & .00 \\
\hline $1900-1904$ & .06 & -0.17 & -0.82 & 0.21 & $F(20,38)=$ & 17.56 & .00 \\
\hline 1905-1909 & .43 & -0.58 & -2.76 & 0.21 & $F(20,38)=$ & 20.50 & .00 \\
\hline $1910-1914$ & .71 & -0.78 & -4.98 & 0.16 & $F(20,36)=$ & 31.45 & .00 \\
\hline 1915-1919 & .21 & 0.43 & 1.40 & 0.31 & $F(14,29)=$ & 8.20 & .00 \\
\hline $1920-1924$ & .06 & -0.25 & -0.76 & 0.33 & $F(18,32)=$ & 5.77 & .00 \\
\hline 1925-1929 & .00 & 0.05 & 0.15 & 0.33 & $F(20,38)=$ & 11.61 & .00 \\
\hline $1930-1934$ & .06 & -0.06 & -0.85 & 0.08 & $F(20,38)=$ & 8.21 & .00 \\
\hline 1935-1939 & .08 & -0.10 & -0.97 & 0.11 & $F(19,34)=$ & 5.36 & .00 \\
\hline $1940-1944$ & .06 & 0.17 & 0.66 & 0.26 & $F(14,29)=$ & 6.01 & .00 \\
\hline 1945-1949 & .41 & -0.30 & -2.53 & 0.12 & $F(17,30)=$ & 9.30 & .00 \\
\hline $1950-1954$ & .17 & -0.07 & -1.46 & 0.05 & $F(20,38)=$ & 6.19 & .00 \\
\hline 1955-1959 & .04 & -0.06 & -0.68 & 0.10 & $F(20,38)=$ & 9.11 & .00 \\
\hline $1960-1964$ & .04 & -0.06 & -0.68 & 0.10 & $F(20,38)=$ & 4.69 & .00 \\
\hline $1965-1969$ & .00 & 0.00 & 0.01 & 0.11 & $F(20,38)=$ & 9.36 & .00 \\
\hline $1970-1974$ & .01 & 0.03 & 0.41 & 0.08 & $F(20,38)=$ & 2.59 & .01 \\
\hline 1975-1979 & .04 & -0.09 & -0.65 & 0.15 & $F(20,38)=$ & 6.90 & .00 \\
\hline $1980-1984$ & .03 & 0.11 & 0.58 & 0.19 & $F(20,38)=$ & 5.99 & .00 \\
\hline 1985-1989 & .00 & 0.02 & 0.14 & 0.21 & $F(20,38)=$ & 10.41 & .00 \\
\hline
\end{tabular}

Notes and sources:

See text and data appendix. 
Table 4

Sinn's Cross-Section Coefficient

\begin{tabular}{|c|c|c|c|c|c|c|c|c|}
\hline Year & $\mathrm{b}$ & s.e. $(\mathrm{N})$ & Year & b & s.e. $(\mathbf{N})$ & Year & $b$ & s.e. $(\mathrm{N})$ \\
\hline 1860 & 0.63 & $0.50(3)$ & 1905 & 0.31 & $0.25(12)$ & 1950 & 1.04 & $0.13(12)$ \\
\hline 1861 & 0.43 & $0.22(6)$ & 1906 & 0.55 & 0.24 (12) & 1951 & 0.77 & $0.06(12)$ \\
\hline 1862 & 0.21 & $0.16(6)$ & 1907 & 0.32 & 0.39 (12) & 1952 & 0.79 & $0.23(12)$ \\
\hline 1863 & 0.17 & $0.25(6)$ & 1908 & 1.02 & $0.31(12)$ & 1953 & 1.03 & $0.15(12)$ \\
\hline 1864 & -0.02 & $0.23(6)$ & 1909 & 0.85 & $0.36(12)$ & 1954 & 1.17 & $0.09(12)$ \\
\hline 1865 & 0.10 & $0.19(7)$ & 1910 & 0.83 & 0.47 (12) & 1955 & 0.93 & $0.13(12)$ \\
\hline 1866 & 0.07 & $0.17(7)$ & 1911 & 0.25 & $0.40(12)$ & 1956 & 0.91 & $0.10(12)$ \\
\hline 1867 & 0.58 & $0.31(7)$ & 1912 & 0.67 & $0.54(12)$ & 1957 & 0.88 & $0.13(12)$ \\
\hline 1868 & 0.74 & $0.22(7)$ & 1913 & 0.48 & $0.40(12)$ & 1958 & 0.97 & 0.15 (12) \\
\hline 1869 & 0.28 & $0.24(7)$ & 1914 & 0.25 & $0.80(10)$ & 1959 & 0.94 & $0.11(12)$ \\
\hline 1870 & -0.16 & $0.31(8)$ & 1915 & 0.43 & $0.17(9)$ & 1960 & 0.86 & $0.11(12)$ \\
\hline 1871 & -0.19 & $0.31(8)$ & 1916 & 0.48 & $0.10(9)$ & 1961 & 0.92 & $0.13(12)$ \\
\hline 1872 & 0.16 & $0.36(8)$ & 1917 & 0.45 & $0.10(9)$ & 1962 & 0.97 & $0.10(12)$ \\
\hline 1873 & -0.15 & $0.36(8)$ & 1918 & 0.45 & $0.09(9)$ & 1963 & 1.07 & $0.10(12)$ \\
\hline 1874 & 0.36 & $0.24(10)$ & 1919 & 0.75 & $0.18(9)$ & 1964 & 0.91 & $0.14(12)$ \\
\hline 1875 & 0.51 & $0.44(10)$ & 1920 & 0.60 & $0.29(9)$ & 1965 & 0.85 & $0.15(12)$ \\
\hline 1876 & 0.82 & $0.26(10)$ & 1921 & 0.50 & $0.23(10)$ & 1966 & 0.90 & $0.16(12)$ \\
\hline 1877 & 0.61 & $0.29(10)$ & 1922 & 0.52 & $0.20(11)$ & 1967 & 0.93 & $0.14(12)$ \\
\hline 1878 & 0.54 & $0.30(10)$ & 1923 & 0.30 & $0.18(11)$ & 1968 & 0.87 & $0.09(12)$ \\
\hline 1879 & 0.90 & $0.27(10)$ & 1924 & 0.62 & $0.21(11)$ & 1969 & 0.85 & $0.07(12)$ \\
\hline 1880 & 0.77 & $0.19(10)$ & 1925 & 0.41 & $0.13(12)$ & 1970 & 0.91 & $0.08(12)$ \\
\hline 1881 & 0.85 & $0.33(10)$ & 1926 & 0.31 & $0.10(12)$ & 1971 & 0.89 & $0.10(12)$ \\
\hline 1882 & 0.35 & $0.28(10)$ & 1927 & 0.42 & $0.18(12)$ & 1972 & 0.83 & $0.06(12)$ \\
\hline 1883 & 0.53 & $0.34(10)$ & 1928 & 1.11 & 0.19 (12) & 1973 & 0.94 & $0.12(12)$ \\
\hline 1884 & 0.35 & $0.30(10)$ & 1929 & 0.61 & $0.22(12)$ & 1974 & 0.91 & $0.15(12)$ \\
\hline 1885 & 0.19 & $0.25(12)$ & 1930 & 0.60 & $0.18(12)$ & 1975 & 1.00 & $0.17(12)$ \\
\hline 1886 & 0.25 & $0.26(12)$ & 1931 & 1.07 & $0.16(12)$ & 1976 & 0.79 & $0.20(12)$ \\
\hline 1887 & 0.48 & $0.22(12)$ & 1932 & 0.81 & $0.16(12)$ & 1977 & 0.78 & $0.22(12)$ \\
\hline 1888 & 0.28 & $0.22(12)$ & 1933 & 0.92 & $0.07(12)$ & 1978 & 0.78 & $0.11(12)$ \\
\hline 1889 & 0.23 & 0.15 (12) & 1934 & 0.96 & $0.11(12)$ & 1979 & 0.79 & $0.09(12)$ \\
\hline 1890 & 0.07 & $0.14(12)$ & 1935 & 0.97 & $0.12(12)$ & 1980 & 0.76 & $0.13(12)$ \\
\hline 1891 & 0.83 & $0.27(12)$ & 1936 & 0.80 & 0.14 (11) & 1981 & 0.75 & $0.16(12)$ \\
\hline 1892 & 0.70 & $0.19(12)$ & 1937 & 0.84 & 0.17 (11) & 1982 & 0.74 & $0.11(12)$ \\
\hline 1893 & 0.61 & $0.15(12)$ & 1938 & 0.93 & 0.09 (11) & 1983 & 0.62 & $0.12(12)$ \\
\hline 1894 & 0.55 & $0.13(12)$ & 1939 & 0.90 & $0.12(10)$ & 1984 & 0.53 & $0.12(12)$ \\
\hline 1895 & 0.62 & $0.14(12)$ & 1940 & 0.51 & $0.14(9)$ & 1985 & 0.49 & $0.15(12)$ \\
\hline 1896 & 0.57 & $0.16(12)$ & 1941 & 0.47 & $0.14(9)$ & 1986 & 0.70 & $0.18(12)$ \\
\hline 1897 & 0.60 & $0.13(12)$ & 1942 & 0.65 & $0.13(9)$ & 1987 & 0.69 & $0.15(12)$ \\
\hline 1898 & 0.57 & $0.17(12)$ & 1943 & 0.68 & $0.13(9)$ & 1988 & 0.69 & $0.17(12)$ \\
\hline 1899 & 0.71 & $0.22(12)$ & 1944 & 0.69 & $0.15(9)$ & 1989 & 0.65 & $0.19(12)$ \\
\hline 1900 & 0.70 & $0.14(12)$ & 1945 & 0.49 & $0.10(8)$ & 1990 & 0.67 & $0.19(12)$ \\
\hline 1901 & 0.70 & $0.18(12)$ & 1946 & 0.83 & $0.33(10)$ & 1991 & 0.65 & $0.14(12)$ \\
\hline 1902 & 0.78 & $0.20(12)$ & 1947 & 1.27 & $0.28(10)$ & 1992 & 0.59 & $0.14(12)$ \\
\hline 1903 & 0.83 & $0.19(12)$ & 1948 & 1.11 & $0.10(10)$ & & & \\
\hline 1904 & 0.66 & $0.21(12)$ & 1949 & 1.11 & 0.15 (11) & & & \\
\hline
\end{tabular}

Notes and Sources:

b is the estimated coefficient, s.e. is the standard error, and $\mathbf{N}$ is the sample size.

1850-1859 omitted, since $N=2$ before 1860 . See text and data appendix. 
Table 5

Error Correction Model of Saving-Investment Relationshlp

\begin{tabular}{|c|c|c|c|c|c|c|c|c|c|c|c|}
\hline & & $\mathbf{T}$ & R sq. & a & $b$ & c & d & R1 & $\mathrm{R} 2$ & R3 & R4 \\
\hline Argentina & $1880-1913$ & 28 & .12 & $\begin{array}{r}0.02 \\
(1.38)\end{array}$ & $\begin{array}{r}-0.06 \\
(0.84)\end{array}$ & $\begin{array}{r}0.16 \\
(1.32)\end{array}$ & $\begin{array}{r}-0.18 \\
(1.45)\end{array}$ & .00 & .35 & .29 & .00 \\
\hline Argentina & 1914-1945 & 32 & .19 & $\begin{array}{r}0.03 \\
(2.08)\end{array}$ & $\begin{array}{r}-0.05 \\
(0.98)\end{array}$ & $\begin{array}{r}0.25 \\
(1.86)\end{array}$ & $\begin{array}{r}-0.29 \\
(2.13)\end{array}$ & .00 & .10 & .05 & \\
\hline Argentina & $1946-1971$ & 26 & .59 & $\begin{array}{r}0.03 \\
(1.50)\end{array}$ & $\begin{array}{r}0.55 \\
(4.90)\end{array}$ & $\begin{array}{r}0.43 \\
(2.87)\end{array}$ & $\begin{array}{r}-0.15 \\
(1.56)\end{array}$ & .00 & .03 & .00 & \\
\hline Argentina & $1972-1992$ & 21 & .40 & $\begin{array}{r}0.00 \\
(0.18)\end{array}$ & $\begin{array}{r}0.56 \\
(3.18)\end{array}$ & $\begin{array}{r}0.38 \\
(1.68)\end{array}$ & $\begin{array}{r}-0.06 \\
(0.60)\end{array}$ & .03 & .24 & .01 & \\
\hline Australia & $1880-1913$ & 34 & .61 & $\begin{array}{r}0.01 \\
(0.81)\end{array}$ & $\begin{array}{r}0.58 \\
(5.95)\end{array}$ & $\begin{array}{r}0.16 \\
(1.51)\end{array}$ & $\begin{array}{r}-0.05 \\
(0.41)\end{array}$ & .00 & .26 & .00 & .00 \\
\hline Australia & 1914-1945 & 32 & .48 & $\begin{array}{r}-0.01 \\
(0.42)\end{array}$ & $\begin{array}{r}0.63 \\
(3.80)\end{array}$ & $\begin{array}{r}0.70 \\
(4.07)\end{array}$ & $\begin{array}{r}0.19 \\
(1.26)\end{array}$ & .00 & .00 & .00 & \\
\hline Australia & $1946-1971$ & 26 & .81 & $\begin{array}{r}0.07 \\
(2.25)\end{array}$ & $\begin{array}{r}-0.11 \\
(0.65)\end{array}$ & $\begin{array}{r}0.89 \\
(7.74)\end{array}$ & $\begin{array}{r}-0.25 \\
(1.87)\end{array}$ & .00 & .00 & .11 & \\
\hline Australia & 1972-1992 & 21 & .59 & $\begin{array}{r}0.04 \\
(0.83)\end{array}$ & $\begin{array}{r}0.88 \\
(3.74)\end{array}$ & $\begin{array}{r}0.60 \\
(2.57)\end{array}$ & $\begin{array}{r}-0.14 \\
(0.73)\end{array}$ & .23 & .05 & .00 & \\
\hline Canada & $1880-1913$ & 34 & .62 & $\begin{array}{r}-0.01 \\
(1.32)\end{array}$ & $\begin{array}{r}0.85 \\
(6.74)\end{array}$ & $\begin{array}{r}0.08 \\
(1.09)\end{array}$ & $\begin{array}{r}0.16 \\
(2.68)\end{array}$ & .00 & .04 & .00 & .00 \\
\hline Canada & $1914-1945$ & 32 & .63 & $\begin{array}{r}-0.02 \\
(1.10)\end{array}$ & $\begin{array}{r}0.49 \\
(4.30)\end{array}$ & $\begin{array}{r}0.39 \\
(5.27)\end{array}$ & $\begin{array}{r}0.09 \\
(0.79)\end{array}$ & .00 & .00 & .00 & \\
\hline Canada & 1946 & 26 & .64 & $\begin{array}{r}0.04 \\
(1.37)\end{array}$ & $\begin{array}{r}0.29 \\
(2.03)\end{array}$ & $\begin{array}{r}0.38 \\
(4.50)\end{array}$ & $\begin{array}{r}-0.14 \\
(1.09)\end{array}$ & .00 & .00 & .01 & \\
\hline Canada & 1972-1992 & 21 & .39 & $\begin{array}{r}0.02 \\
(0.60)\end{array}$ & $\begin{array}{r}0.67 \\
(2.98)\end{array}$ & $\begin{array}{r}0.32 \\
(1.40)\end{array}$ & $\begin{array}{r}-0.08 \\
(0.51)\end{array}$ & .03 & .35 & .02 & \\
\hline Denmark & $1880-1913$ & 34 & .30 & $\begin{array}{r}0.01 \\
(0.59)\end{array}$ & $\begin{array}{r}0.22 \\
(1.41)\end{array}$ & $\begin{array}{r}0.46 \\
(3.56)\end{array}$ & $\begin{array}{r}0.06 \\
(0.92)\end{array}$ & .00 & .00 & .34 & .00 \\
\hline Denmark & 1914-1945 & 25 & .31 & $\begin{array}{r}0.05 \\
(1.20)\end{array}$ & $\begin{array}{r}0.33 \\
(1.55)\end{array}$ & $\begin{array}{r}0.72 \\
(2.90)\end{array}$ & $\begin{array}{r}-0.32 \\
(1.29)\end{array}$ & .41 & .03 & .07 & \\
\hline Denmark & $1946-$ & 26 & .79 & $\begin{array}{r}0.13 \\
(6.52)\end{array}$ & $\begin{array}{r}0.48 \\
(4.20)\end{array}$ & $\begin{array}{r}1.07 \\
(7.33)\end{array}$ & $\begin{array}{c}-0.48 \\
(6.07)\end{array}$ & .70 & .00 & .00 & \\
\hline Denmark & $1972-1992$ & 21 & .25 & $\begin{array}{r}-0.01 \\
(0.19)\end{array}$ & $\begin{array}{r}0.73 \\
(1.94)\end{array}$ & $\begin{array}{r}0.06 \\
(0.37)\end{array}$ & $\begin{array}{r}0.01 \\
(0.06)\end{array}$ & .00 & .91 & .15 & \\
\hline France & $1880-1913$ & 34 & .60 & $\begin{array}{r}0.08 \\
(3.99)\end{array}$ & $\begin{array}{r}0.35 \\
(3.34)\end{array}$ & $\begin{array}{r}0.52 \\
(3.82)\end{array}$ & $\begin{array}{r}-0.56 \\
(3.99)\end{array}$ & .00 & .00 & .00 & .00 \\
\hline France & 191 & 16 & .82 & $\begin{array}{r}-0.02 \\
(0.87)\end{array}$ & $\begin{array}{r}0.76 \\
(5.98)\end{array}$ & $\begin{array}{r}0.07 \\
(0.36)\end{array}$ & $\begin{array}{r}0.13 \\
(0.84)\end{array}$ & .00 & .20 & .00 & \\
\hline France & $1946-1971$ & 22 & .45 & $\begin{array}{r}0.01 \\
(0.22)\end{array}$ & $\begin{array}{r}0.39 \\
(2.44)\end{array}$ & $\begin{array}{r}0.44 \\
(2.86)\end{array}$ & $\begin{array}{r}-0.05 \\
(0.24)\end{array}$ & .01 & .01 & .02 & \\
\hline France & 1972-1992 & 21 & .68 & $\begin{array}{r}0.01 \\
(0.38)\end{array}$ & $\begin{array}{r}0.67 \\
(2.46)\end{array}$ & $\begin{array}{r}0.95 \\
(3.36)\end{array}$ & $\begin{array}{r}-0.04 \\
(0.50)\end{array}$ & .40 & .01 & .02 & \\
\hline Germany & $1880-1913$ & 34 & .88 & $\begin{array}{r}-0.02 \\
(2.21)\end{array}$ & $\begin{array}{r}0.93 \\
(13.07)\end{array}$ & $\begin{array}{r}0.69 \\
(4.18)\end{array}$ & $\begin{array}{r}0.04 \\
(0.75)\end{array}$ & .05 & .00 & .00 & .00 \\
\hline Germany & 1914 & 10 & .98 & $\begin{array}{r}-0.06 \\
(3.61)\end{array}$ & $\begin{array}{r}1.43 \\
(14.86)\end{array}$ & $\begin{array}{r}1.61 \\
(6.19)\end{array}$ & $\begin{array}{r}0.41 \\
(3.54)\end{array}$ & .08 & .00 & .00 & \\
\hline Gerr & 194 & 21 & .80 & $\begin{array}{r}-0.05 \\
(1.93)\end{array}$ & $\begin{array}{r}1.07 \\
(6.75)\end{array}$ & $\begin{array}{r}0.69 \\
(3.77)\end{array}$ & $\begin{array}{r}0.12 \\
(1.31)\end{array}$ & .24 & .00 & .00 & \\
\hline Germany & $1972-1992$ & 21 & .56 & $\begin{array}{r}0.03 \\
(1.04)\end{array}$ & $\begin{array}{r}0.64 \\
(3.14)\end{array}$ & $\begin{array}{r}0.18 \\
(1.30)\end{array}$ & $\begin{array}{r}-0.15 \\
(1.24)\end{array}$ & .00 & .38 & .00 & \\
\hline
\end{tabular}


Table 5 (continued)

Error Correctlon Model of Saving-Investment Relationship

\begin{tabular}{|c|c|c|c|c|c|c|c|c|c|c|c|}
\hline & & $\mathrm{T}$ & R sq. & $\mathrm{a}$ & b & c & $d$ & R1 & $\mathrm{R} 2$ & R3 & $\mathrm{R} 4$ \\
\hline Italy & $1880-1913$ & 34 & .93 & $\begin{array}{r}-0.01 \\
(1.16)\end{array}$ & $\begin{array}{r}0.93 \\
(17.15)\end{array}$ & $\begin{array}{r}0.15 \\
(1.29)\end{array}$ & $\begin{array}{r}0.06 \\
(1.02)\end{array}$ & .00 & .07 & .00 & .00 \\
\hline Italy & 1914-1945 & 32 & .74 & $\begin{array}{r}0.05 \\
(3.61)\end{array}$ & $\begin{array}{r}0.66 \\
(8.17)\end{array}$ & $\begin{array}{r}0.56 \\
(3.39)\end{array}$ & $\begin{array}{r}-0.31 \\
(3.84)\end{array}$ & .00 & .00 & .00 & \\
\hline Italy & $1946-1971$ & 26 & .90 & $\begin{array}{r}-0.01 \\
(0.25)\end{array}$ & $\begin{array}{r}1.05 \\
(8.82)\end{array}$ & $\begin{array}{r}0.56 \\
(3.56)\end{array}$ & $\begin{array}{r}0.02 \\
(0.17)\end{array}$ & .00 & .00 & .00 & \\
\hline Italy & 1972-1992 & 21 & .56 & $\begin{array}{r}-0.02 \\
(0.50)\end{array}$ & $\begin{array}{r}1.18 \\
(2.97) \\
\end{array}$ & $\begin{array}{r}0.68 \\
(2.93)\end{array}$ & $\begin{array}{r}0.10 \\
(0.55) \\
\end{array}$ & .39 & .03 & .03 & \\
\hline Japan & $1880-1913$ & 28 & .19 & $\begin{array}{r}0.06 \\
(2.25)\end{array}$ & $\begin{array}{r}0.03 \\
(0.20)\end{array}$ & $\begin{array}{r}0.30 \\
(1.88)\end{array}$ & $\begin{array}{r}-0.35 \\
(2.09)\end{array}$ & .00 & .08 & .09 & .00 \\
\hline Japan & 1914-1945 & 31 & .66 & $\begin{array}{r}0.01 \\
(0.37)\end{array}$ & $\begin{array}{r}0.58 \\
(6.70)\end{array}$ & $\begin{array}{r}0.20 \\
(1.63)\end{array}$ & $\begin{array}{c}-0.03 \\
(0.39)\end{array}$ & .00 & .16 & .00 & \\
\hline Japan & $1946-1971$ & 25 & .76 & $\begin{array}{r}0.00 \\
(0.42)\end{array}$ & $\begin{array}{r}1.14 \\
(7.34)\end{array}$ & $\begin{array}{r}0.54 \\
(2.68)\end{array}$ & $\begin{array}{r}0.00 \\
(0.10)\end{array}$ & .07 & .04 & .00 & \\
\hline Japan & 1972-1992 & 21 & .64 & $\begin{array}{r}-0.06 \\
(1.89) \\
\end{array}$ & $\begin{array}{r}0.94 \\
(3.60) \\
\end{array}$ & $\begin{array}{r}0.37 \\
(2.09) \\
\end{array}$ & $\begin{array}{r}0.17 \\
(1.70) \\
\end{array}$ & .00 & .03 & .01 & \\
\hline Norway & $1880-1913$ & 34 & .18 & $\begin{array}{r}0.00 \\
(0.15)\end{array}$ & $\begin{array}{r}0.25 \\
(1.98)\end{array}$ & $\begin{array}{r}0.10 \\
(1.05)\end{array}$ & $\begin{array}{r}0.00 \\
(0.03)\end{array}$ & .00 & .25 & .15 & .00 \\
\hline Norway & 1914-1945 & 26 & .71 & $\begin{array}{r}-0.02 \\
(0.54)\end{array}$ & $\begin{array}{r}0.71 \\
(4.83)\end{array}$ & $\begin{array}{r}0.39 \\
(1.92)\end{array}$ & $\begin{array}{r}0.13 \\
(0.71)\end{array}$ & .01 & .01 & .00 & \\
\hline Norway & $1946-1971$ & 25 & .58 & $\begin{array}{r}0.08 \\
(1.52)\end{array}$ & $\begin{array}{r}0.72 \\
(4.05)\end{array}$ & $\begin{array}{r}0.51 \\
(2.60)\end{array}$ & $\begin{array}{r}-0.22 \\
(1.37)\end{array}$ & .05 & .04 & .00 & \\
\hline Norway & 1972-1992 & 21 & .22 & $\begin{array}{r}-0.08 \\
(0.91)\end{array}$ & $\begin{array}{r}-0.36 \\
(1.24)\end{array}$ & $\begin{array}{r}0.02 \\
(0.18)\end{array}$ & $\begin{array}{r}0.25 \\
(0.82)\end{array}$ & .00 & .48 & .27 & \\
\hline Sweden & $1880-1913$ & 34 & .52 & $\begin{array}{r}0.02 \\
(1.64)\end{array}$ & $\begin{array}{r}0.39 \\
(4.52)\end{array}$ & $\begin{array}{r}0.31 \\
(2.47)\end{array}$ & $\begin{array}{r}-0.10 \\
(1.16)\end{array}$ & .00 & .03 & .00 & .10 \\
\hline Sweden & 1914-1945 & 32 & .72 & $\begin{array}{r}0.02 \\
(1.48)\end{array}$ & $\begin{array}{r}0.37 \\
(8.00)\end{array}$ & $\begin{array}{r}0.30 \\
(2.46)\end{array}$ & $\begin{array}{r}-0.12 \\
(1.55)\end{array}$ & .00 & .04 & .00 & \\
\hline Sweden & $1946-1971$ & 26 & .37 & $\begin{array}{r}0.02 \\
(1.02)\end{array}$ & $\begin{array}{r}0.44 \\
(3.09)\end{array}$ & $\begin{array}{r}0.53 \\
(3.00)\end{array}$ & $\begin{array}{r}-0.10 \\
(0.98)\end{array}$ & .03 & .02 & .01 & \\
\hline Sweden & 1972-1992 & 21 & .52 & $\begin{array}{r}-0.02 \\
(0.52)\end{array}$ & $\begin{array}{r}0.58 \\
(2.20)\end{array}$ & $\begin{array}{r}0.54 \\
(2.54)\end{array}$ & $\begin{array}{r}0.06 \\
(0.36)\end{array}$ & .02 & .03 & .10 & \\
\hline U.K. & $1880-1913$ & 34 & .92 & $\begin{array}{r}0.08 \\
(5.12)\end{array}$ & $\begin{array}{r}0.58 \\
(6.28)\end{array}$ & $\begin{array}{r}0.36 \\
(4.35)\end{array}$ & $\begin{array}{r}-0.76 \\
(5.48)\end{array}$ & .00 & .00 & .00 & .00 \\
\hline U.K. & 1914-1945 & 32 & .65 & $\begin{array}{r}0.01 \\
(1.24)\end{array}$ & $\begin{array}{r}0.30 \\
(6.71)\end{array}$ & $\begin{array}{r}0.19 \\
(1.98)\end{array}$ & $\begin{array}{r}-0.08 \\
(1.11)\end{array}$ & .00 & .04 & .00 & \\
\hline U.K. & $1946-1971$ & 26 & .59 & $\begin{array}{r}0.03 \\
(2.52)\end{array}$ & $\begin{array}{r}0.27 \\
(1.66)\end{array}$ & $\begin{array}{r}0.19 \\
(0.91)\end{array}$ & $\begin{array}{r}-0.14 \\
(2.32)\end{array}$ & .00 & .09 & .01 & \\
\hline U.K. & 1972-1992 & 21 & .33 & $\begin{array}{r}0.03 \\
(0.74) \\
\end{array}$ & $\begin{array}{r}0.67 \\
(2.25)\end{array}$ & $\begin{array}{r}0.34 \\
(1.86)\end{array}$ & $\begin{array}{r}-0.17 \\
(0.69)\end{array}$ & .01 & .21 & .07 & \\
\hline U.S.A. & $1880-1913$ & 34 & .51 & $\begin{array}{r}0.01 \\
(0.41)\end{array}$ & $\begin{array}{r}0.68 \\
(5.55)\end{array}$ & $\begin{array}{r}0.09 \\
(1.11)\end{array}$ & $\begin{array}{c}-0.03 \\
(0.45)\end{array}$ & .00 & .54 & .00 & .05 \\
\hline U.S.A. & 1914-1945 & 32 & .94 & $\begin{array}{r}0.01 \\
(1.30)\end{array}$ & $\begin{array}{r}0.92 \\
(18.54)\end{array}$ & $\begin{array}{r}0.25 \\
(2.20)\end{array}$ & $\begin{array}{r}-0.07 \\
(1.99)\end{array}$ & .00 & .07 & .00 & \\
\hline U.S.A. & $1946-1971$ & 26 & .94 & $\begin{array}{r}0.00 \\
(0.09)\end{array}$ & $\begin{array}{r}0.87 \\
(11.02)\end{array}$ & $\begin{array}{r}0.52 \\
(2.99)\end{array}$ & $\begin{array}{r}0.00 \\
(0.05)\end{array}$ & .01 & .02 & .00 & \\
\hline U.S.A. & 1972-1992 & 21 & .81 & $\begin{array}{r}0.01 \\
(0.44) \\
\end{array}$ & $\begin{array}{r}1.09 \\
(7.98) \\
\end{array}$ & $\begin{array}{r}0.19 \\
(1.31) \\
\end{array}$ & $\begin{array}{r}-0.03 \\
(0.30) \\
\end{array}$ & .00 & .40 & .00 & \\
\hline
\end{tabular}

Notes:

See text and appendix. 
Table 6

Error Correctlon Model of Saving-Investment Relationshlp:

Pass Through and Adjustment Speeds

\begin{tabular}{lrrrr} 
& $b$ & $b$ & $b$ & $b$ \\
Country & $1880-1913$ & $1914-1945$ & $1946-1971$ & $1972-1992$ \\
\hline Argentina & -0.06 & -0.05 & 0.55 & 0.56 \\
Australia & 0.58 & 0.63 & -0.11 & 0.88 \\
Canada & 0.85 & 0.49 & 0.29 & 0.67 \\
Denmark & 0.22 & 0.33 & 0.48 & 0.73 \\
France & 0.35 & 0.76 & 0.39 & 0.67 \\
Germany & 0.93 & 1.43 & 1.07 & 0.64 \\
Italy & 0.93 & 0.66 & 1.05 & 1.18 \\
Japan & 0.03 & 0.58 & 1.14 & 0.94 \\
Norway & 0.25 & 0.71 & 0.72 & -0.36 \\
Sweden & 0.39 & 0.37 & 0.44 & 0.58 \\
U.K. & 0.58 & 0.30 & 0.27 & 0.67 \\
U.S.A. & 0.68 & 0.92 & 0.87 & 1.09 \\
\hline Average & 0.48 & 0.59 & 0.60 & 0.69 \\
s.d. & 0.32 & 0.35 & 0.37 & 0.37 \\
\hline & & & & \\
Country & $1880-1913$ & $1914-1945$ & $1946-1971$ & $1972-1992$ \\
\hline Argentina & 0.16 & 0.25 & 0.43 & 0.38 \\
Australia & 0.16 & 0.70 & 0.89 & 0.60 \\
Canada & 0.08 & 0.39 & 0.38 & 0.32 \\
Denmark & 0.46 & 0.72 & 1.07 & 0.06 \\
France & 0.52 & 0.07 & 0.44 & 0.95 \\
Germany & 0.69 & 1.61 & 0.69 & 0.18 \\
Italy & 0.15 & 0.56 & 0.56 & 0.68 \\
Japan & 0.30 & 0.20 & 0.54 & 0.37 \\
Norway & 0.10 & 0.39 & 0.51 & 0.02 \\
Sweden & 0.31 & 0.30 & 0.53 & 0.54 \\
U.K. & 0.36 & 0.19 & 0.19 & 0.34 \\
U.S.A. & 0.09 & 0.25 & 0.52 & 0.19 \\
\hline Average & 0.28 & 0.47 & 0.56 & 0.39 \\
s.d. & 0.19 & 0.39 & 0.22 & 0.26 \\
CA half-life & 1.8 & 1.1 & 0.9 & 1.3 \\
\hline & & & &
\end{tabular}

Notes:

See text.

Source:

Table 5. 
Appendix Table 1

Saving Pates

\begin{tabular}{|c|c|c|c|c|c|c|c|c|c|c|c|c|}
\hline & ARG & AUS & CAN & DNK & FRA & DEU & ITA & JPN & NOR & SWE & GBR & USA \\
\hline 1850 & - & - & - & - & .150 & - & - & - & - & - & .095 & - \\
\hline 1851 & - & - & - & - & .161 & - & - & - & - & - & .100 & - \\
\hline 1852 & - & - & - & - & .157 & - & - & - & - & - & .115 & - \\
\hline 1853 & - & - & - & - & .153 & - & - & - & - & - & .105 & - \\
\hline 1854 & - & - & - & - & .157 & - & - & - & - & - & .104 & - \\
\hline 1855 & - & - & - & - & .133 & - & - & - & - & - & .114 & - \\
\hline 1856 & - & - & - & - & .153 & - & - & - & - & - & .111 & - \\
\hline 1857 & - & - & - & - & .176 & - & - & - & - & - & .095 & - \\
\hline 1858 & - & - & - & - & .182 & - & - & - & - & - & .110 & - \\
\hline 1859 & - & - & - & - & .177 & - & - & - & - & - & .125 & - \\
\hline 1860 & - & - & - & - & .168 & .122 & - & - & - & - & .096 & - \\
\hline 1861 & - & .069 & - & - & .113 & .072 & .032 & - & - & .027 & .100 & - \\
\hline 1862 & - & .014 & - & - & .166 & .123 & .074 & - & - & .077 & .101 & - \\
\hline 1863 & - & .055 & - & - & .170 & .135 & .054 & - & - & .074 & .137 & - \\
\hline 1864 & - & .069 & - & - & .174 & .112 & .061 & - & - & .084 & .127 & - \\
\hline 1865 & - & .054 & - & - & .181 & .096 & .075 & - & .110 & .077 & .149 & - \\
\hline 1866 & - & .035 & - & - & .167 & .094 & .080 & - & .114 & .076 & .134 & - \\
\hline 1867 & - & .113 & - & - & .134 & .071 & .073 & - & .129 & .057 & .125 & - \\
\hline 1868 & - & .124 & - & - & .147 & .140 & 102 & - & .113 & .014 & .116 & - \\
\hline 1869 & - & .064 & - & - & .157 & .071 & .105 & - & .151 & .063 & .128 & - \\
\hline 1870 & - & .098 & .094 & - & .127 & .119 & .082 & - & .149 & .119 & .158 & - \\
\hline 1871 & - & .104 & .069 & - & .086 & .104 & .105 & - & .155 & .104 & .150 & - \\
\hline 1872 & - & .189 & .079 & - & .162 & .154 & .088 & - & .177 & .116 & .152 & - \\
\hline 1873 & - & .133 & .080 & - & .155 & .146 & .114 & - & .184 & .102 & .164 & - \\
\hline 1874 & - & .119 & .087 & .134 & .172 & .164 & .076 & - & .173 & .102 & .198 & .213 \\
\hline 1875 & - & .147 & .107 & .135 & .167 & .134 & .100 & - & .147 & .107 & .152 & .200 \\
\hline 1876 & - & .126 & .103 & .132 & .110 & .135 & .069 & - & .175 & .092 & .125 & .199 \\
\hline 1877 & - & .085 & .085 & .106 & .138 & .110 & .071 & - & .133 & .076 & .083 & .204 \\
\hline 1878 & - & .107 & .077 & .117 & .099 & .115 & .095 & - & .156 & .087 & .146 & .206 \\
\hline 1879 & - & .112 & .092 & .111 & .085 & .086 & .099 & - & .153 & .087 & .069 & .206 \\
\hline 1880 & - & .171 & .102 & .123 & .115 & .088 & .142 & - & .158 & .079 & .163 & .217 \\
\hline 1881 & - & .137 & .088 & .107 & .138 & .104 & .069 & - & .149 & .060 & .128 & .210 \\
\hline 1882 & - & .046 & .109 & .119 & .131 & .105 & .148 & - & .176 & .063 & .123 & .202 \\
\hline 1883 & - & .109 & .124 & .104 & .118 & .106 & .131 & - & .156 & .051 & .143 & .196 \\
\hline 1884 & - & .052 & .154 & .100 & .128 & .122 & .115 & - & .153 & .052 & .148 & .198 \\
\hline 1885 & .059 & .041 & .089 & .096 & .120 & .121 & .113 & .117 & .143 & .036 & .125 & .200 \\
\hline 1886 & .005 & .069 & .074 & .126 & .109 & .120 & .144 & .134 & .150 & .057 & .139 & .203 \\
\hline 1887 & -.017 & .139 & .086 & .117 & .130 & .127 & .103 & .112 & .165 & .043 & .142 & .205 \\
\hline 1888 & -.020 & .083 & .089 & .090 & .121 & .137 & .122 & .147 & .172 & .063 & .131 & .218 \\
\hline 1889 & -.136 & .085 & .082 & .094 & .142 & .146 & .035 & .148 & .182 & .059 & .144 & .218 \\
\hline 1890 & -.149 & .080 & .059 & .119 & .139 & .148 & .087 & .115 & .167 & .056 & .155 & .230 \\
\hline 1891 & .136 & .126 & .080 & .112 & .112 & .098 & .076 & .152 & .131 & .053 & .125 & .232 \\
\hline 1892 & .067 & .059 & .075 & .115 & .133 & .127 & .116 & .148 & .140 & .060 & .122 & .234 \\
\hline 1893 & -.039 & .074 & .077 & .112 & .134 & .125 & .069 & .135 & .145 & .097 & .106 & .231 \\
\hline 1894 & -.059 & .075 & .062 & .115 & .132 & .120 & .086 & .153 & .136 & .083 & .135 & .228 \\
\hline 1895 & .031 & \multicolumn{2}{|c|}{.00060 .076} & .122 & .154 & .116 & .098 & .157 & .126 & .119 & .122 & .217 \\
\hline 1896 & -.002 & .036 & .079 & .144 & .149 & .143 & .069 & .141 & .118 & .141 & .134 & .224 \\
\hline 1897 & -.010 & \multicolumn{2}{|c|}{.00050 .109} & .177 & .143 & .155 & .149 & .154 & .133 & .134 & .108 & .228 \\
\hline 1898 & .040 & .006 & .128 & .173 & .137 & .183 & .121 & .116 & .127 & .098 & .131 & .235 \\
\hline 1899 & .081 & .083 & .116 & .186 & .174 & .167 & .184 & .168 & .126 & .092 & .148 & .239 \\
\hline
\end{tabular}


Appendix Table 1 (continued)

Saving Rates

\begin{tabular}{|c|c|c|c|c|c|c|c|c|c|c|c|c|}
\hline & ARG & AUS & CAN & DNK & FRA & DEU & ITA & JPN & NOR & SWE & GBR & USA \\
\hline 1900 & .055 & .053 & .130 & .172 & .167 & .157 & .189 & .131 & .125 & .100 & .112 & .238 \\
\hline 1901 & .059 & .112 & .152 & .177 & .150 & .126 & .148 & .155 & .104 & .089 & .135 & .236 \\
\hline 1902 & .082 & .149 & .157 & .188 & .158 & .116 & .182 & .138 & .110 & .079 & .120 & .231 \\
\hline 1903 & .083 & .090 & .170 & .201 & .148 & .145 & .161 & .131 & .105 & .110 & .118 & .227 \\
\hline 1904 & .080 & .164 & .162 & .186 & .164 & .159 & .169 & .074 & .123 & .090 & .127 & .226 \\
\hline 1905 & .145 & .123 & .162 & .182 & .169 & .175 & .198 & .058 & .117 & .101 & .150 & .228 \\
\hline 1906 & .077 & .165 & .162 & .171 & .141 & .163 & .274 & .153 & .139 & .109 & .151 & .225 \\
\hline 1907 & .088 & .197 & .167 & .163 & .159 & .167 & .177 & .165 & 141 & .107 & .150 & .226 \\
\hline 1908 & .103 & .148 & .187 & .169 & .154 & .134 & .220 & .153 & .137 & .095 & .135 & .219 \\
\hline 1909 & .112 & .163 & .177 & .154 & .155 & .134 & .138 & .153 & .130 & .074 & .148 & .208 \\
\hline 1910 & .085 & .177 & .180 & .165 & .133 & .138 & .153 & .158 & .161 & .105 & .149 & .207 \\
\hline 1911 & .032 & .166 & .164 & .163 & .128 & .152 & .186 & .171 & .165 & .142 & .162 & .212 \\
\hline 1912 & .052 & .149 & .163 & .153 & 149 & .161 & .175 & .156 & .180 & .136 & .152 & .199 \\
\hline 1913 & .034 & .182 & .177 & .159 & 142 & .160 & .191 & .150 & .204 & .150 & .181 & .195 \\
\hline 1914 & .193 & .165 & .162 & .202 & - & - & .139 & .167 & .189 & .193 & .148 & .204 \\
\hline 1915 & .244 & .084 & .149 & - & - & - & .019 & .205 & .247 & .238 & .023 & .165 \\
\hline 1916 & .101 & .097 & .144 & - & - & - & -.103 & .272 & .294 & .321 & .054 & .183 \\
\hline 1917 & .060 & .087 & .180 & - & - & - & -.168 & .325 & .223 & .316 & .042 & .166 \\
\hline 1918 & .074 & .075 & .133 & - & - & - & -.161 & .300 & .177 & .200 & -.021 & .088 \\
\hline 1919 & .127 & .082 & .147 & - & - & - & -.029 & .216 & .347 & .078 & .031 & .117 \\
\hline 1920 & -.029 & .144 & .135 & - & - & - & .044 & .224 & .191 & .077 & .132 & .136 \\
\hline 1921 & -.097 & .158 & .138 & .176 & - & - & .058 & .177 & .137 & .119 & .123 & .096 \\
\hline 1922 & .004 & .201 & .128 & .155 & .155 & - & .123 & .181 & .134 & .154 & .122 & .131 \\
\hline 1923 & -.041 & .162 & .202 & .146 & .157 & - & .169 & .133 & .139 & .136 & .113 & .155 \\
\hline 1924 & .056 & .151 & .186 & .167 & .203 & - & .207 & .147 & .147 & .136 & .098 & .147 \\
\hline 1925 & -.045 & .207 & .192 & .184 & .182 & .188 & .210 & .151 & .174 & .152 & .097 & .157 \\
\hline 1926 & -.044 & .120 & .189 & .181 & .213 & .173 & .183 & .158 & .170 & .157 & .083 & .156 \\
\hline 1927 & .000 & .119 & .183 & .169 & .175 & .209 & .152 & .170 & .147 & .183 & .108 & .150 \\
\hline 1928 & .113 & .151 & .198 & .165 & .193 & .206 & .188 & .158 & .159 & .155 & .111 & .131 \\
\hline 1929 & .083 & .127 & .177 & .190 & .197 & .161 & .182 & .178 & .186 & .196 & .108 & .153 \\
\hline 1930 & .038 & .061 & .147 & .199 & .209 & .142 & .144 & .088 & .214 & .181 & .096 & .124 \\
\hline 1931 & .138 & .096 & .138 & .187 & .182 & .071 & .164 & .064 & .162 & .140 & .067 & .062 \\
\hline 1932 & .167 & .113 & .091 & .163 & .142 & .058 & .160 & .109 & .182 & .123 & .067 & .007 \\
\hline 1933 & .088 & .103 & .086 & .168 & .146 & .129 & .140 & .129 & .191 & .168 & .079 & .011 \\
\hline 1934 & .146 & .134 & .114 & .180 & .141 & .155 & .147 & .144 & .199 & .184 & .087 & .044 \\
\hline 1935 & .153 & .112 & .137 & .201 & .145 & .193 & .194 & .160 & .217 & .178 & .098 & .087 \\
\hline 1936 & .171 & .121 & .168 & .184 & .142 & - & .185 & .160 & .238 & .190 & .096 & .083 \\
\hline 1937 & .167 & .160 & .180 & .196 & .136 & - & .201 & .145 & .261 & .203 & .096 & .129 \\
\hline 1938 & .106 & .164 & .157 & .202 & .133 & - & .184 & .177 & .262 & .204 & .093 & .081 \\
\hline 1939 & .139 & .137 & .146 & .204 & - & - & .206 & .229 & .251 & .186 & .047 & .097 \\
\hline 1940 & .137 & .161 & .152 & .194 & - & - & .150 & .210 & - & .157 & -.036 & .135 \\
\hline 1941 & .159 & .090 & .191 & .167 & - & - & .143 & .184 & - & .184 & -.038 & .150 \\
\hline 1942 & .179 & .064 & .107 & .162 & - & - & .093 & .168 & - & .210 & -.022 & .069 \\
\hline 1943 & .219 & .020 & .129 & .180 & - & - & .041 & .209 & - & .217 & -.031 & .030 \\
\hline 1944 & .184 & .095 & .080 & .159 & - & - & -.040 & .236 & - & .199 & -.037 & .014 \\
\hline 1945 & .196 & .087 & .159 & .160 & - & - & -.076 & - & - & .286 & -.052 & .028 \\
\hline 1946 & .206 & .169 & .177 & .128 & - & - & .163 & .162 & .261 & .209 & .069 & .168 \\
\hline 1947 & .172 & .198 & .179 & .197 & - & - & .211 & .202 & .275 & .173 & .076 & .181 \\
\hline 1948 & .135 & .215 & .225 & .239 & - & - & .191 & .198 & .328 & .192 & .121 & .194 \\
\hline 1949 & .119 & .212 & .214 & .233 & .202 & - & .201 & .205 & .339 & .234 & .125 & .140 \\
\hline
\end{tabular}


Appendix Table 1 (continued)

Saving Rates

\begin{tabular}{|c|c|c|c|c|c|c|c|c|c|c|c|c|}
\hline & ARG & AUS & CAN & DNK & FRA & DEU & ITA & JPN & NOR & SWE & GBA & USA \\
\hline 1950 & .149 & .211 & .191 & .234 & .239 & .219 & .212 & .205 & .370 & .220 & .151 & .182 \\
\hline 1951 & .171 & .282 & .180 & .261 & .270 & .240 & .218 & .222 & .369 & .219 & .104 & .176 \\
\hline 1952 & .147 & .171 & .215 & .254 & .241 & .246 & .169 & .218 & .346 & .198 & .144 & .149 \\
\hline 1953 & 190 & .255 & .205 & .272 & .229 & .239 & .185 & .210 & .312 & .217 & .149 & .137 \\
\hline 1954 & .160 & .247 & .205 & .249 & .250 & .248 & .196 & .215 & .320 & .210 & .150 & .139 \\
\hline 1955 & .151 & .217 & .203 & .250 & .268 & .267 & .215 & .208 & .268 & .200 & .141 & .169 \\
\hline 1956 & .141 & .228 & .209 & .258 & .297 & .267 & .211 & .235 & .367 & .206 & .161 & .180 \\
\hline 1957 & .140 & .255 & .218 & .283 & .258 & .267 & .225 & .246 & .293 & .202 & .166 & .171 \\
\hline 1958 & .146 & .225 & .217 & .278 & .253 & .261 & .232 & .264 & .283 & .209 & 169 & .141 \\
\hline 1959 & .168 & .237 & .198 & .297 & .259 & .265 & .242 & .276 & .278 & .221 & .165 & .162 \\
\hline 1960 & .230 & .248 & .193 & .248 & .257 & .299 & .290 & .333 & .280 & .245 & .172 & .194 \\
\hline 1961 & .317 & .249 & .196 & .235 & .255 & .294 & .303 & .353 & .281 & .251 & .180 & .187 \\
\hline 1962 & .228 & .254 & .194 & .229 & .253 & .286 & .294 & .344 & .270 & .249 & .168 & .194 \\
\hline 1963 & .201 & .272 & .202 & .231 & .248 & .278 & .269 & .329 & .271 & .245 & .170 & .197 \\
\hline 1964 & .260 & .271 & .220 & .242 & .259 & .296 & .263 & .344 & .277 & .266 & .187 & .202 \\
\hline 1965 & .264 & .254 & .222 & .248 & .266 & .287 & .255 & .333 & .290 & .261 & .189 & .210 \\
\hline 1966 & .252 & .265 & .234 & .233 & .268 & .282 & .246 & .340 & .290 & .250 & .191 & .208 \\
\hline 1967 & .249 & .244 & .232 & .222 & .267 & .266 & .250 & .356 & .288 & .248 & .188 & 197 \\
\hline 1968 & .225 & .273 & .219 & .226 & .259 & .281 & .253 & .379 & .282 & .239 & .197 & .195 \\
\hline 1969 & .242 & .273 & .209 & .237 & .263 & .290 & .266 & .392 & .267 & .240 & .204 & .198 \\
\hline 1970 & .231 & .272 & .227 & .227 & .274 & .296 & .275 & .403 & .292 & .248 & .205 & .184 \\
\hline 1971 & .238 & .269 & .227 & .229 & .273 & .285 & .256 & .385 & .283 & .240 & .206 & 193 \\
\hline 1972 & .236 & .276 & .218 & .254 & .274 & .280 & .248 & .378 & .284 & .234 & .185 & .195 \\
\hline 1973 & .235 & .263 & .230 & .242 & .281 & .282 & .251 & .381 & .297 & .239 & .195 & .209 \\
\hline 1974 & .235 & .245 & .227 & .223 & .271 & .264 & .260 & .366 & .307 & .229 & .172 & .196 \\
\hline 1975 & .308 & .246 & .218 & .199 & .247 & .227 & .239 & .328 & .285 & .239 & .169 & .182 \\
\hline 1976 & .346 & .246 & .217 & .193 & .247 & .238 & .258 & .326 & .276 & .216 & .192 & .187 \\
\hline 1977 & .333 & .223 & .214 & .192 & .246 & .233 & .260 & .325 & .256 & .186 & .206 & .193 \\
\hline 1978 & .308 & .242 & .211 & .193 & .245 & .237 & .264 & .326 & .276 & .185 & .209 & .207 \\
\hline 1979 & .259 & .248 & .216 & .185 & .243 & .240 & .258 & .316 & .302 & .189 & .201 & .208 \\
\hline 1980 & .238 & .236 & .232 & .175 & .230 & .229 & .243 & .313 & .338 & .193 & 191 & .193 \\
\hline 1981 & .223 & .238 & .228 & .162 & .209 & .217 & .228 & .319 & .335 & .179 & .180 & .204 \\
\hline 1982 & .243 & .204 & .229 & .167 & .200 & .218 & .224 & .307 & .322 & .170 & .175 & .176 \\
\hline 1983 & .247 & .221 & .211 & .180 & .197 & .223 & .225 & .298 & .326 & .193 & .173 & .168 \\
\hline 1984 & .226 & .221 & .202 & .197 & .196 & .228 & .227 & .308 & .348 & .213 & .171 & .184 \\
\hline 1985 & .235 & .221 & .198 & .199 & .195 & .231 & .221 & .315 & .324 & .209 & .182 & .172 \\
\hline 1986 & .193 & .221 & .193 & .211 & .207 & .247 & .225 & .318 & .259 & .211 & .164 & .162 \\
\hline 1987 & .199 & .233 & .193 & .208 & .203 & .244 & .217 & .318 & .262 & .207 & .169 & .157 \\
\hline 1988 & .220 & .244 & .198 & .211 & .215 & .253 & .217 & .329 & .263 & .215 & .167 & .161 \\
\hline 1989 & .220 & .235 & .229 & .217 & .224 & .263 & .213 & .332 & .287 & .225 & .169 & .167 \\
\hline 1990 & .195 & .211 & .206 & .229 & .223 & .273 & .211 & .335 & .281 & .217 & .165 & .157 \\
\hline 1991 & .162 & .194 & .188 & .230 & .215 & .281 & .207 & .342 & .276 & .195 & .148 & .147 \\
\hline 1992 & .151 & .190 & .181 & .228 & .209 & .280 & .196 & .336 & .256 & .183 & .137 & .148 \\
\hline
\end{tabular}

Sources:

See data appendix. 
Appendix Table 2

Investment Rates

\begin{tabular}{|c|c|c|c|c|c|c|c|c|c|c|c|c|}
\hline & ARG & AUS & CAN & DNK & FRA & DEU & ITA & JPN & NOR & SWE & GBR & JSA \\
\hline 1850 & - & - & - & - & .109 & - & - & - & - & - & .076 & 二 \\
\hline 1851 & - & - & - & - & .108 & - & - & - & - & - & .083 & - \\
\hline 1852 & - & - & - & - & .117 & - & - & - & - & - & .091 & - \\
\hline 1853 & - & - & - & - & .109 & - & - & - & - & - & .091 & - \\
\hline 1854 & - & - & - & - & .130 & - & - & - & - & - & .091 & - \\
\hline 1855 & - & - & - & - & .117 & - & - & - & - & - & .086 & - \\
\hline 1856 & - & - & - & - & .140 & - & - & - & - & - & .082 & - \\
\hline 1857 & - & - & - & - & .157 & - & - & - & - & - & .070 & - \\
\hline 1858 & - & - & - & - & .141 & - & - & - & - & - & .068 & - \\
\hline 1859 & - & - & - & - & .115 & - & - & - & - & - & .080 & - \\
\hline 1860 & - & - & - & - & .122 & .121 & - & - & - & - & .070 & - \\
\hline 1861 & - & .110 & - & - & .117 & .071 & .074 & - & - & .064 & .086 & - \\
\hline 1862 & - & .108 & - & - & .139 & .121 & .104 & - & - & .093 & .085 & - \\
\hline 1863 & - & .147 & - & - & .133 & .133 & .088 & - & - & .083 & .105 & - \\
\hline 1864 & - & .146 & - & - & .124 & .110 & .114 & - & - & .090 & .100 & - \\
\hline 1865 & - & .126 & - & - & .129 & .094 & .124 & - & .129 & .078 & .110 & - \\
\hline 1866 & - & .111 & - & - & .120 & .091 & .110 & - & .134 & .092 & .092 & - \\
\hline 1867 & - & .143 & - & - & .115 & .068 & .092 & - & .129 & .074 & .077 & - \\
\hline 1868 & - & .154 & - & - & .144 & .137 & .114 & - & .130 & .046 & .078 & - \\
\hline 1869 & - & .122 & - & - & .131 & .068 & .118 & - & .121 & .088 & .081 & - \\
\hline 1870 & - & .140 & .157 & - & .102 & .114 & .092 & - & .122 & .115 & .110 & - \\
\hline 1871 & - & .088 & .152 & - & .092 & .097 & .089 & - & .125 & .098 & .087 & - \\
\hline 1872 & - & .163 & .174 & - & .121 & .144 & .084 & - & .150 & .110 & .075 & - \\
\hline 1873 & - & .176 & .173 & - & .112 & .122 & .117 & - & .169 & .121 & .100 & - \\
\hline 1874 & - & .166 & .191 & .145 & .133 & .159 & .092 & - & .184 & .139 & .142 & .226 \\
\hline 1875 & - & .206 & .188 & .146 & .120 & .125 & .102 & - & .182 & .136 & .109 & .211 \\
\hline 1876 & - & .177 & .166 & .137 & .098 & .123 & .063 & - & .170 & .122 & .100 & .199 \\
\hline 1877 & - & .178 & .141 & .125 & .120 & .097 & .078 & - & .171 & .123 & .075 & .196 \\
\hline 1878 & - & .202 & .135 & .111 & .116 & .094 & .086 & - & .157 & .114 & .128 & .193 \\
\hline 1879 & - & .188 & .126 & .111 & .121 & .067 & .102 & - & .148 & .102 & .042 & .196 \\
\hline 1880 & - & .200 & .137 & .111 & .158 & .073 & .134 & - & .147 & .098 & .139 & .199 \\
\hline 1881 & - & .234 & .136 & .125 & .165 & .085 & .060 & - & .146 & .102 & .082 & .200 \\
\hline 1882 & - & .166 & .173 & .131 & .154 & .081 & .142 & - & .150 & .091 & .077 & .200 \\
\hline 1883 & - & .199 & .198 & .138 & .146 & .093 & .124 & - & .151 & .096 & .108 & .197 \\
\hline 1884 & - & .168 & .222 & .142 & .147 & .098 & .123 & - & .147 & .108 & .097 & .201 \\
\hline 1885 & .112 & .193 & .157 & .133 & .137 & .097 & .146 & .120 & .143 & .101 & .078 & .204 \\
\hline 1886 & .089 & .217 & .152 & .114 & .124 & .096 & .171 & .126 & .138 & .112 & .080 & .208 \\
\hline 1887 & .082 & .234 & .163 & .123 & .135 & .107 & .146 & .122 & .143 & .084 & .077 & .210 \\
\hline 1888 & .110 & .208 & .168 & .126 & .128 & .107 & .135 & .154 & .146 & .096 & .065 & .224 \\
\hline 1889 & .113 & .198 & .170 & .133 & .134 & .122 & .053 & .148 & .164 & .105 & .086 & .227 \\
\hline 1890 & .159 & .199 & .144 & .135 & .137 & .131 & .104 & .145 & .178 & .103 & .082 & .237 \\
\hline 1891 & .118 & .220 & .150 & .132 & .134 & .085 & .074 & .140 & .172 & .080 & .077 & .237 \\
\hline 1892 & .071 & .137 & .139 & .130 & .136 & .120 & .110 & .136 & .163 & .082 & .080 & .240 \\
\hline 1893 & .069 & .108 & .135 & .132 & .134 & .111 & .065 & .138 & .163 & .092 & .067 & .236 \\
\hline 1894 & .063 & .121 & .115 & .131 & .140 & .096 & .067 & .164 & .164 & .089 & .102 & .232 \\
\hline 1895 & .066 & .081 & .123 & .142 & .140 & .103 & .083 & .162 & .168 & .116 & .087 & .220 \\
\hline 1896 & .076 & .119 & .115 & .170 & .138 & .123 & .050 & .182 & .163 & .126 & .103 & .215 \\
\hline 1897 & .076 & .063 & .126 & .190 & .130 & .133 & .122 & .205 & .176 & .131 & .083 & .212 \\
\hline 1898 & .077 & .102 & .154 & .226 & .149 & .158 & .099 & .194 & .189 & .126 & .114 & .210 \\
\hline 1899 & .063 & .091 & .153 & .230 & .160 & .157 & .148 & .162 & .207 & .135 & .122 & .213 \\
\hline
\end{tabular}


Appendix Table 2 (continued)

Investment Rates

\begin{tabular}{|c|c|c|c|c|c|c|c|c|c|c|c|c|}
\hline & ARG & AUS & CAN & DNK & FRA & DEU & ITA & JPN & NOR & SWE & GBR & SA \\
\hline 1900 & .082 & .094 & 155 & .218 & .160 & .145 & .174 & .162 & .187 & .133 & .094 & .216 \\
\hline 1901 & .079 & .131 & .182 & .201 & .136 & .114 & .119 & .153 & .176 & .120 & .125 & .218 \\
\hline 1902 & .079 & .182 & . 1866 & .216 & .135 & .102 & .145 & .132 & .168 & .117 & .108 & .215 \\
\hline 1903 & .076 & .126 & .217 & .211 & .141 & .133 & .131 & .136 & .159 & .133 & .096 & .215 \\
\hline 1904 & .100 & .163 & .230 & .210 & .138 & .143 & .137 & .120 & .168 & .139 & .101 & .218 \\
\hline 1905 & .136 & .106 & .229 & .196 & .137 & .144 & .147 & .168 & .157 & .132 & .108 & .219 \\
\hline 1906 & .155 & .136 & .236 & .224 & .121 & .152 & .238 & .164 & .174 & .138 & .093 & .212 \\
\hline 1907 & .187 & .165 & .259 & .222 & .147 & .163 & .170 & .169 & .192 & .138 & .074 & .216 \\
\hline 19 & .145 & .132 & .265 & .204 & .142 & .122 & .226 & .176 & .191 & .117 & .065 & .216 \\
\hline 1909 & .156 & .161 & .259 & .195 & .138 & .126 & .150 & .158 & .172 & .106 & .082 & .208 \\
\hline 1910 & .174 & .175 & .295 & .188 & .128 & .123 & .152 & .176 & .182 & .111 & .070 & .204 \\
\hline 1911 & .168 & .167 & .311 & .182 & .151 & .139 & .185 & .193 & .205 & .132 & .075 & 209 \\
\hline 1912 & .127 & .168 & .341 & .191 & .156 & .153 & .180 & .180 & .211 & .128 & .066 & .197 \\
\hline 191 & .127 & .216 & .328 & .193 & .147 & .144 & .186 & .172 & .204 & .142 & .088 & .185 \\
\hline 19 & .100 & .193 & .270 & 151 & - & - & .125 & .170 & .205 & .165 & .095 & .183 \\
\hline 191 & .073 & .116 & . 174 & - & - & - & .058 & .159 & .198 & .177 & .039 & .125 \\
\hline 15 & .071 & .164 & .153 & - & - & - & .018 & .168 & .210 & .217 & .030 & .122 \\
\hline 19 & .067 & .102 & . 147 & - & - & - & .037 & .211 & .242 & .222 & .031 & .112 \\
\hline 15 & .049 & .102 & .127. & - & - & - & .039 & .228 & .157 & .163 & .030 & .060 \\
\hline 15 & .058 & .136 & 151 & - & - & - & .087 & .190 & .358 & .134 & .039 & .072 \\
\hline 15 & .07 & .12 & .16 & - & - & - & .15 & .226 & .30 & .136 & .077 & .105 \\
\hline 192 & .08 & .263 & .17 & 177 & - & - & .110 & .193 & .23 & .125 & .086 & .072 \\
\hline & .10 & .205 & .15 & .183 & 139 & - & .146 & .191 & .193 & .139 & .080 & .122 \\
\hline 19 & .125 & .207 & 18 & .179 & .140 & - & .183 & .168 & .192 & .136 & .073 & .151 \\
\hline & .11 & .205 & 169 & .174 & .167 & - & .203 & .188 & .183 & .135 & .081 & .135 \\
\hline 15 & .1 & .217 & .154 & .181 & .152 & .218 & .218 & .166 & .187 & .143 & .086 & .149 \\
\hline 1926 & .1 & .16 & .15 & .178 & .174 & .155 & .189 & .179 & .17 & .143 & .087 & .151 \\
\hline 1927 & .120 & .193 & .17 & .167 & .147 & .242 & .157 & .177 & .16 & .156 & .088 & .143 \\
\hline 192 & .126 & .186 & .198 & .161 & .175 & .221 & .211 & .166 & .188 & .146 & .086 & .121 \\
\hline $19 ;$ & .141 & .180 & 222 & .184 & .183 & .163 & .199 & .173 & .195 & .168 & .089 & .146 \\
\hline . & .129 & .164 & 201 & .208 & .208 & .127 & .156 & .085 & .230 & .171 & .089 & .116 \\
\hline 193 & .09 & .127 & 172. & .205 & .191 & .036 & .148 & .071 & .193 & .155 & .090 & .059 \\
\hline 19 & 0 & .097 & .11 & .160 & .164 & .049 & .153 & .106 & .168 & .134 & .079 & .004 \\
\hline 193 & 79 & .109 & .086 & .168 & .157 & .124 & .145 & .125 & .169 & .141 & .081 & .008 \\
\hline 193 & .107 & .122 & .096 & .186 & .146 & .163 & .153 & .143 & .190 & .161 & .091 & .041 \\
\hline 1935 & .123 & .135 & .106 & .190 & .147 & .194 & .208 & .145 & .212 & .172 & .093 & .087 \\
\hline 19 & & .135 & .11 & .183 & .153 & .204 & .182 & .147 & .223 & .178 & .101 & .084 \\
\hline & & .14 & & .180 & .156 & .245 & .215 & .169 & .253 & .187 & .104 & .129 \\
\hline & .1 & .19 & .13 & .18 & .134 & 234 & .1 & .198 & .25 & .197 & .103 & .068 \\
\hline 193 & .10 & .16 & .12 & .193 & - & - & .207 & .225 & .256 & .207 & .088 & .088 \\
\hline 194 & .10 & .185 & .12 & .160 & - & - & .165 & .211 & - & .178 & .068 & .120 \\
\hline 194 & 09 & .123 & 13 & .162 & - & - & .137 & .207 & - & .169 & .054 & .140 \\
\hline 194 & .114 & .090 & 103 & .172 & - & - & .093 & .187 & - & .195 & .046 & .068 \\
\hline 194 & .115 & .032 & 82 & .165 & - & - & .048 & .222 & - & .207 & .035 & .040 \\
\hline 194 & & .029 & & .140 & - & - & .012 & .233 & - & .208 & .029 & .022 \\
\hline & & .035 & .10 & .14 & - & - & .032 & - & - & .224 & .035 & .033 \\
\hline 194 & & .12 & & & - & - & & .165 & .310 & .213 & .092 & 142 \\
\hline 194 & .159 & .195 & .17 & .223 & - & - & .270 & .201 & .372 & .231 & .111 & .142 \\
\hline 1948 & .154 & .210 & .197 & .251 & - & - & .190 & .193 & .365 & .207 & .119 & .187 \\
\hline 1949 & .131 & .194 & .205 & .247 & 276 & - & .188 & .185 & .380 & .218 & .125 & .137 \\
\hline
\end{tabular}


Appendix Table 2 (continued) Investment Rates

\begin{tabular}{|c|c|c|c|c|c|c|c|c|c|c|c|c|}
\hline & ARG & AUS & CAN & DNK & FRA & DEU & ITA & JPN & NOR & SWE & GBR & USA \\
\hline 1950 & 127 & .219 & 209 & 272 & .267 & .223 & .195 & .162 & 354 & .215 & .128 & .189 \\
\hline 1951 & .189 & .243 & 204 & .249 & .260 & .218 & .213 & .201 & .347. & 197 & .129 & .175. \\
\hline 1952 & .172 & .319 & .207 & .248 & .256 & 226 & .188 & .205 & .346. & .194 & .134 & 149 \\
\hline 1953 & .172 & 199 & .222 & .267 & .238 & .211 & .195 & .221 & .352 & 209 & .140 & 142 \\
\hline 1954 & .160 & .248 & .221 & .267 & .247 & .225 & 199 & .218 & .369. & .214 & .144 & .139 \\
\hline 955 & 166 & .262 & .225 & .243 & .252 & .255 & .218 & .198 & .305 & .209 & .149 & 169 \\
\hline 1956 & .154 & .269 & .249 & .260 & .276 & .245 & .215. & .236 & . 366. & .208 & .151 & .176 \\
\hline 1957 & .166 & .231 & .259 & .273 & .274 & .240 & .224 & .266 & .289 & .202 & .156 & .163 \\
\hline 1958 & .166 & .251 & .245 & .252 & .283 & .234 & .213 & .255 & .322 & .213 & .154 & .141 \\
\hline 150 & .164 & .263 & .235 & 294 & .263 & .248 & .218 & .266 & 294 & .221 & .158 & .167 \\
\hline 19 & .229 & .276 & .221 & .260 & .237 & .273 & .295 & .329 & 298 & .251 & .185 & .187 \\
\hline 1 & .271 & .231 & .218 & .251 & .237 & .272 & .305 & .369 & .311 & .247 & .183 & .179 \\
\hline 15 & .212 & .260 & .212 & .261 & .244 & .273 & .301 & .342 & 295 & .246 & .170 & .188 \\
\hline 963 & .178 & .255 & .212 & .228 & .244 & .262 & .294 & .338 & .293 & .243 & .174 & .190 \\
\hline 15 & .209 & .290 & .228 & .262 & .261 & .281 & .264 & .346 & .279 & .263 & .204 & .192 \\
\hline 196 & .219 & .276 & .242 & .264 & .257 & .284 & .234 & .319 & 299 & 269 & .197 & .203 \\
\hline 1966 & 197 & .274 & .252 & 249 & .265 & .265 & .230 & .324 & .305 & 257 & .192 & .203 \\
\hline & .209 & .266 & .240 & .242 & .265 & .230 & .242 & .354 & .306 & .248 & .198 & .193 \\
\hline & .218 & .286 & .222 & .240 & .260 & .245 & .234 & .368 & 262 & .241 & .205 & .194 \\
\hline & .239 & .272 & .222 & .258 & .269 & .262 & .254 & .376 & 245 & .243 & .199 & .197 \\
\hline & .252 & .273 & .217 & .257 & .269 & .276 & .274 & .390 & .305 & .254 & .196 & .181 \\
\hline 197 & 240 & .258 & .225 & .248 & .262 & .268 & .249 & .358 & .316 & 229 & .191 & .193 \\
\hline 1972 & .241 & .239 & .223 & .248 & .264 & .259 & .240 & .355 & .27 & .220 & .186 & .199 \\
\hline & .207 & .263 & .230 & .261 & .272 & .253 & .272 & .381 & .301 & .212 & 219 & .207 \\
\hline 15 & .221 & .249 & .239 & .252 & .281 & .220 & .301 & .373 & .336 & .237 & .222 & .198 \\
\hline & 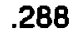 & .242 & .248 & 209 & .235 & .198 & .239 & .328 & .352 & .241 & .186 & .173 \\
\hline 197 & .304 & .252 & .240 & .240 & .254 & .215 & 269 & .318 & .371 & .233 & .203 & .188 \\
\hline 197 & .309. & .233 & .235 & .229 & .244 & .209 & 249 & .308 & .363 & .203 & .198 & .206 \\
\hline 197 & .277 & .252 & .232 & .215 & .232 & .212 & .241 & .309 & .285 & .175 & .195 & .220 \\
\hline 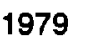 & .259 & .241 & .236 & .213 & .237 & .234 & .247 & .325 & .275 & .199 & .198 & .219 \\
\hline 15 & 253 & .254 & .239 & 185 & .242 & .234 & 270 & .322 & .277 & .212 & .169 & .199 \\
\hline & .227 & .272 & .250 & 155 & 219 & .209 & .247 & .311 & .256 & 181 & .152 & .209 \\
\hline & .218 & .225 & .225 & 163 & .219 & .194 & .235 & .299 & .265. & 176 & .157 & .184 \\
\hline 18 & .208 & .234 & .207 & 160 & .19 & .20 & .21 & .281 & .246 & 171 & .165 & .185 \\
\hline 15 & 200 & .241 & .196 & .184 & .190 & .203 & .229 & .280 & .257 & .177 & .174 & .212 \\
\hline 1985 & .175 & .252 & .201 & .196 & 189 & .196 & .225 & .282 & .242 & 192 & .173 & .202 \\
\hline 1986 & 175 & .238 & .208 & .215 & .196 & .196 & 209 & .278 & 295 & .179 & .171 & .194 \\
\hline 198 & ה & .238 & .214 & 190 & .202 & .194 & 210 & .287 & .282 & .189 & .181 & .190 \\
\hline 198 & .186 & .263 & .222 & 179 & .214 & .200 & .215 & .306 & 271 & .199 & .204 & .184 \\
\hline 198 & .155. & .255 & .232 & .184 & .223 & .20 & .21 & .318 & 243. & .219 & .210 & .184 \\
\hline & 140 & .212 & .209 & .175 & .223 & .21 & .210 & .328 & .205 & .213 & .192 & . 171 \\
\hline 195 & $.14 E$ & .191 & .198 & .16 & .212 & .217 & 205 & .324 & .188 & .179 & .160 & . 152 \\
\hline 1992 & .167 & .195 & .187 & .152 & .197 & .211 & .194 & .311 & 182 & .166 & .153 & .155 \\
\hline
\end{tabular}

Sources:

See data appendix. 
Figure 1

Current Account Relatlve to GDP:

Summary Statistics

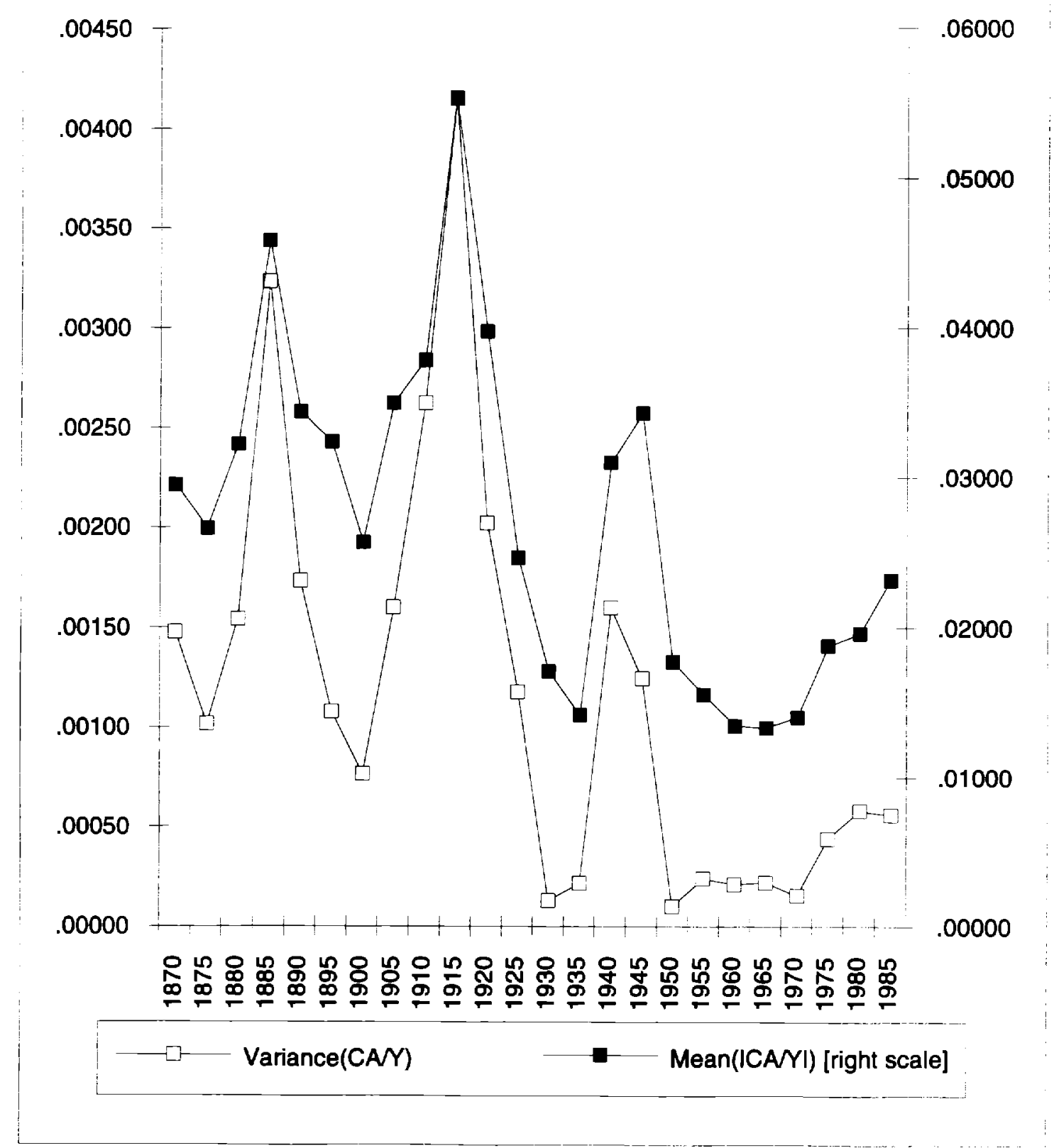

Notes and sources:

See Table 1. 
Figure 2

The FH Correlation In History:

FH Coefficlent \pm 2 standard errors

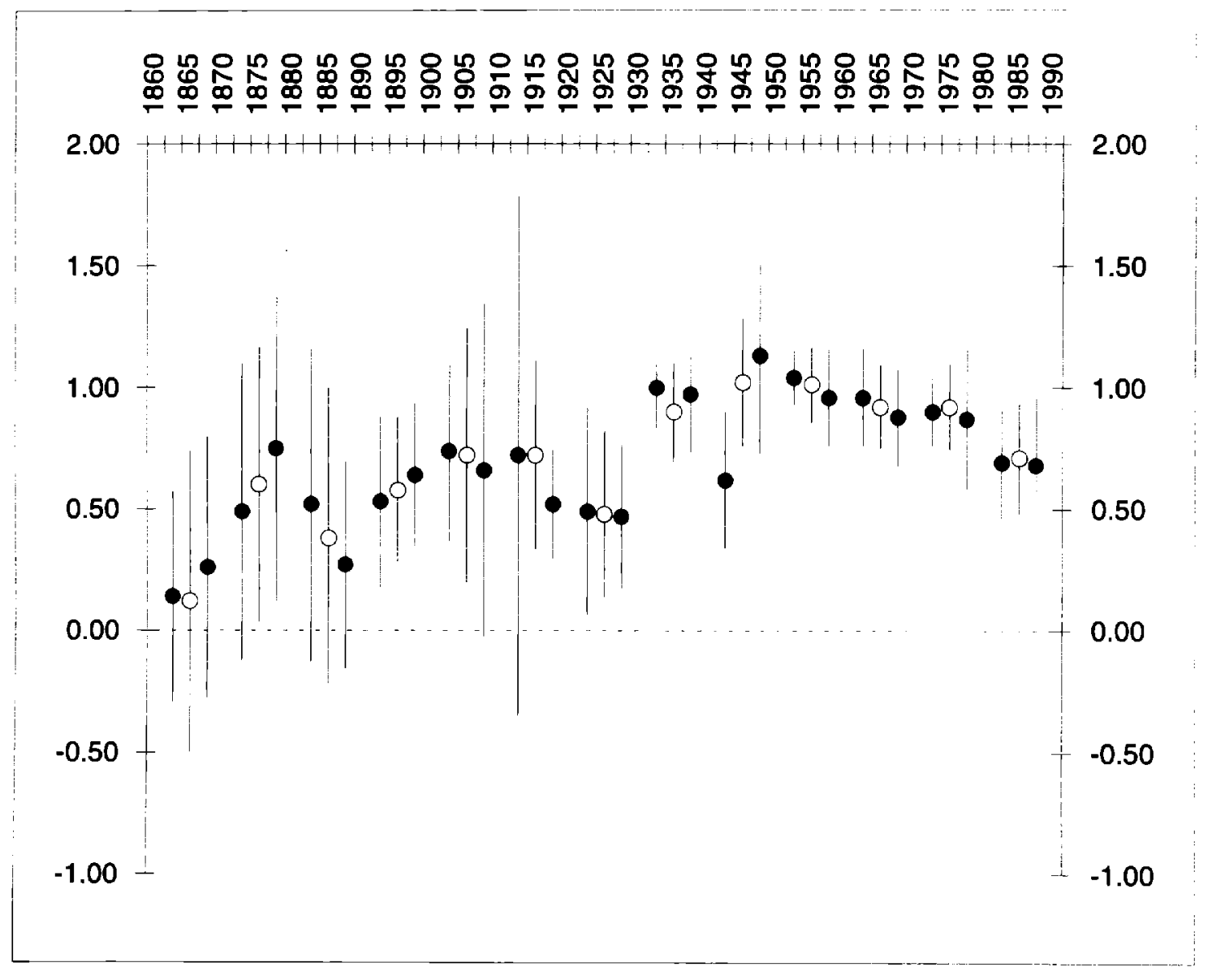

Notes and sources:

See Table 3. 
Figure 3

The FH Correlation In Hlstory:

Alternatlve Measures

$$
(I N)=a+b(S / Y)+e
$$

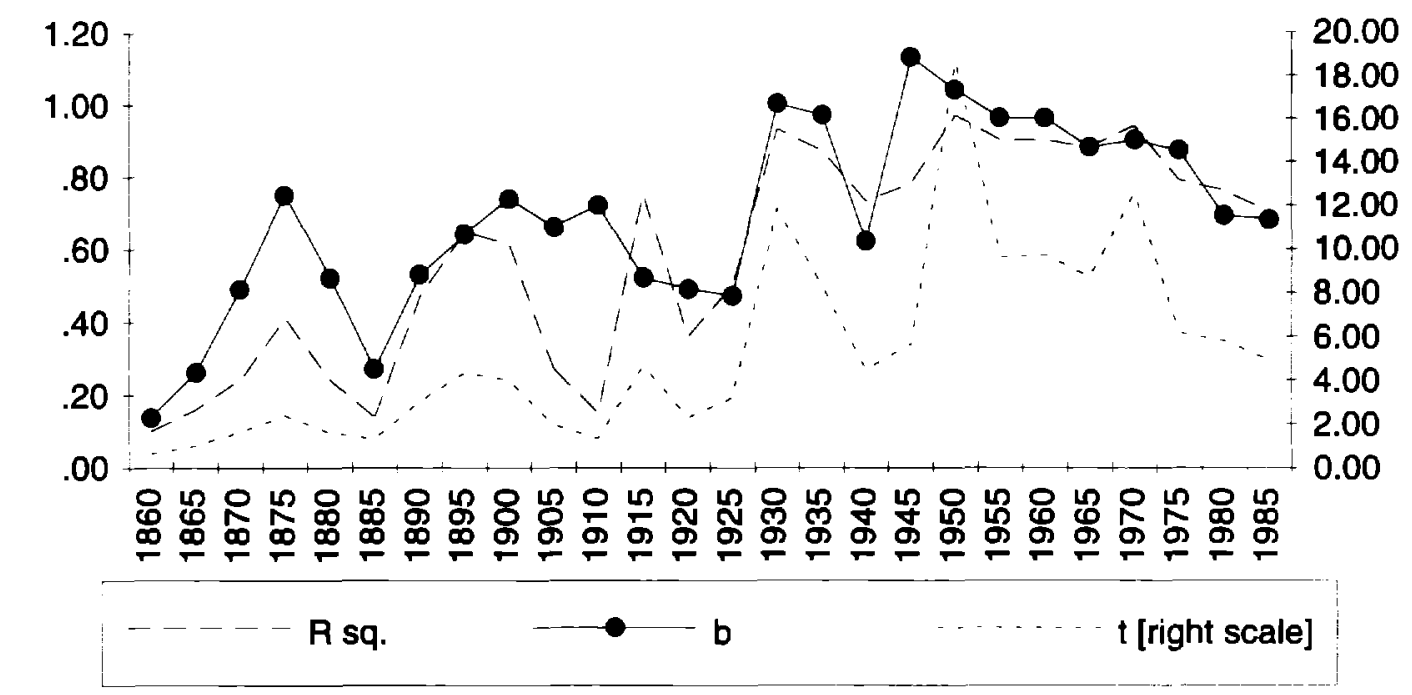

$$
(\mathbf{C A} Y)=a+b(I Y)+e
$$

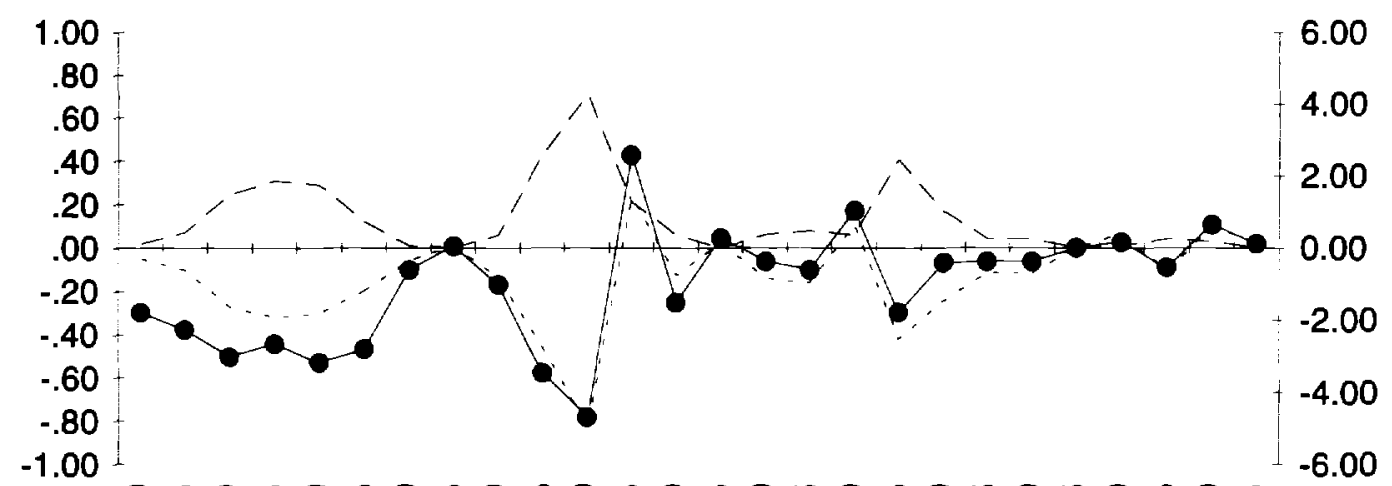

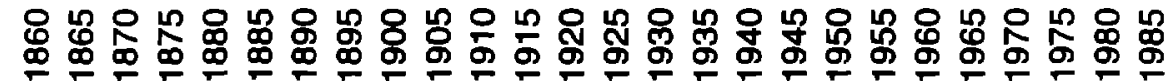

R Sq.

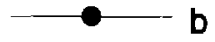

t [right scale]

Notes and Sources:

See Table 3. 
Figure 4

Sinn's Cross-Sectlon Coefficlent \pm 2 standard errors

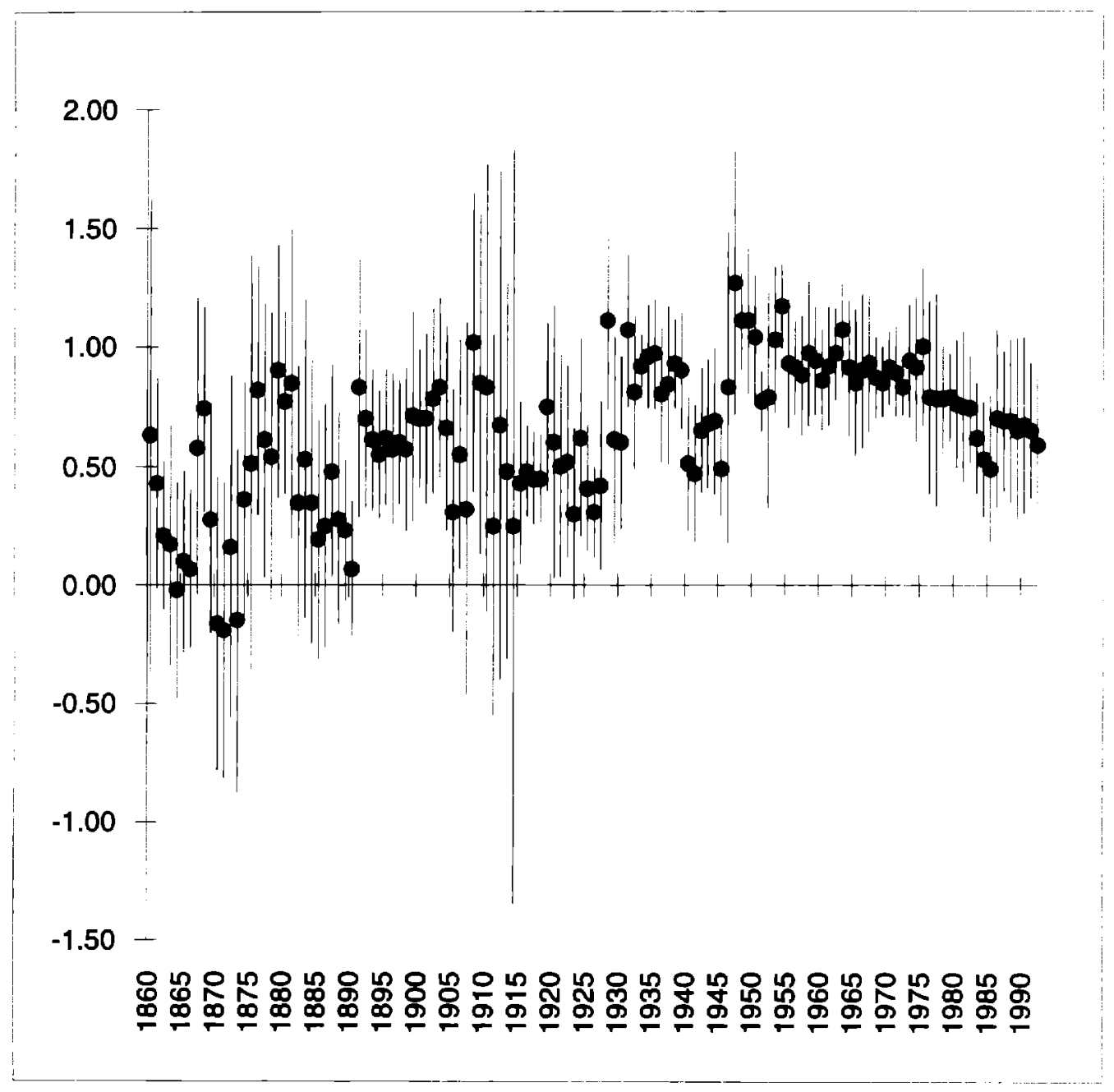

Notes and sources:

See Table 4. 
Figure 5

Error Correction Model of Saving-Investment Relationship:

Pass Through and Adjustment Speeds
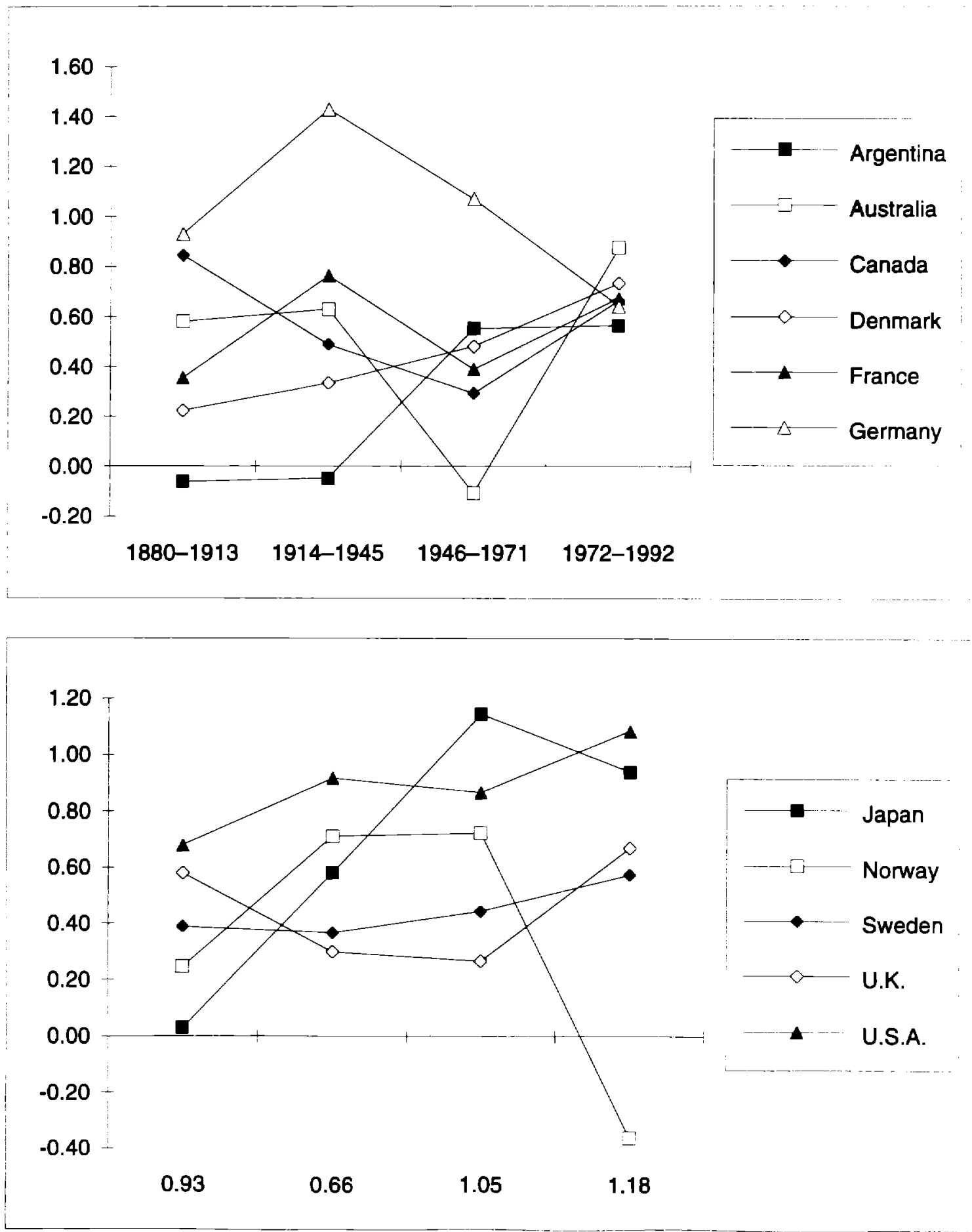

Notes and Sources:

See Table 5. 